\title{
PARENT COMPANY DIRECT LIABILITY FOR OVERSEAS HUMAN RIGHTS VIOLATIONS: LESSONS FROM THE U.K. SUPREME COURT
}

\author{
RACHEL CHAMBERS*
}

\begin{abstract}
Human rights violations are perpetrated by corporate actors with troubling frequency. In most instances, victims do not have access to remedy. For thirty years, the United States has been a beacon of hope, its courts adjudicating human rights claims against corporate defendants under the Alien Tort Statute. Then, in Kiobel v. Royal Dutch Petroleum Co., the Supreme Court closed the door on human rights plaintiffs. This Article charts the rise of the United Kingdom as a venue to bring suit. The U.K. Supreme Court, in a farreaching judgment from 2019, upheld a decision to allow plaintiffs to sue a London-headquartered parent company for grave environmental damage and harm to local communities' livelihoods that occurred through the operations of the company's Zambian subsidiary. The dichotomy in approaches between the U.S. and the U.K. courts has prompted consideration of the following: is there anything that can be drawn from the U.K. litigation to improve

* Postdoctoral Research Associate in Business and Human Rights, Human Rights Institute, University of Connecticut, MA (Oxon), LLM (Kent), PhD (Essex). Barrister-at-law (England and Wales). An earlier version of this Article was presented at the 2019 Big Ten and Friends Business Law Research Symposium at Rutgers Business School. The author is grateful to Robert C. Bird, Wayne Eastman, Julian Jonker, Kevin Kolben, Jeremy Kress, Gideon Mark, and Abbey Stemler for their helpful comments. This Article was presented at the $5^{\text {th }}$ Annual Conference of the Global Business and Human Rights Scholars Association the University of Essex in September 2019. The author is grateful to Robert McCorquodale and Mark Wielga for their helpful comments. In addition, the author thanks Gerlinde BergerWalliser, Doug Cassell, Tyler Giannini, Molly Land, Yonit Manor-Percival, Jena Martin, Peter Muchlinski, Stephen Park, and Karen Weidmann for their invaluable feedback, and Shreya Murthy and Amy Saji for their research assistance.
\end{abstract}


access to remedy in the U.S. courts for victims of human rights violations by corporate actors? This Article concludes that the argument used in the U.K. case law to attribute liability directly to parent companies should be taken up in the United States. 


\section{TABLE OF CONTENTS}

I. Introduction 522

II. Barriers to Transnational Business and Human Rights Litigation: The Role of the Corporate Veil ....................526

a. Business and Human Rights Litigation: The Global

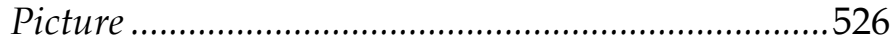

b. The Corporate Veil...................................................528

c. Arguments in Favor of Parent Company Liability .....532

III. Transnational Business and Human Rights Litigation in the United States ..............................................................534

a. The ATS: The Rise and Fall of the Statute ..................535

b. Conventional Tort Litigation ....................................541

c. Overcoming the Corporate Veil..................................544

d. Acuña-Atalaya v. Newmont Mining Corp.................546

i. $\quad$ Veil Piercing / Enterprise Liability ....................547

ii. Agency ..........................................................548

iii. Direct Parent Liability ....................................550

IV. English Cases: On the Rise ...........................................553

a. Background to the Tort Claims ................................553

b. The Current Wave of Litigation ....................................556

i. Lungowe v. Vedanta Resources PLC ...............557

ii. $\quad$ Okpabi v. Royal Dutch Shell PLC....................560

iii. $\quad$ AAA v. Unilever PLC .......................................563

c. Discussion of the Trilogy.........................................564

V. Direct Liability Spreads to Other Jurisdictions..............566

a. Civil Law Jurisdiction Cases in which English Common

Law is the Applicable Law .........................................566

b. Canadian Cases.......................................................571

VI. Direct Liability as a Path Forwards for Plaintiffs in the United States...................................................................574

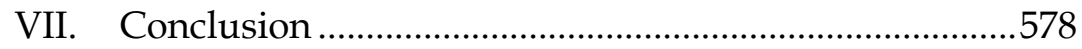




\section{INTRODUCTION}

Impunity for human rights violations by corporate actors is a profound and pervasive injustice in the globalized world. Transnational business frequently operates in places where victims cannot get access to remedy in local courts. There is no international forum that provides an alternative path to justice. For thirty years, until recently, the United States offered a beacon of hope through adjudication of human rights cases against corporate defendants under the Alien Tort Statute ("ATS"). Then, in Kiobel v. Royal Dutch Petroleum Co., the Supreme Court closed the door on human rights plaintiffs by drastically curtailing the ATS. 1 Later rulings of the Supreme Court dealt further blows to plaintiffs by limiting the courts' personal jurisdiction over corporate defendants ${ }^{2}$ and prohibiting ATS claims against foreign companies. ${ }^{3}$ The very question of corporate liability under the statute now hangs in the balance. 4

As one door closes, another has opened. The United Kingdom Supreme Court, in a far-reaching and underreported judgment from 2019, ${ }^{5}$ confirmed a trend of English courts expanding the conditions under which a parent company can be held directly liable under the common law-not international law-for the tortious acts of its

569 U.S. 108 (2013).

2 Daimler AG v. Bauman, 571 U.S. 117 (2014).

3 Jesner v. Arab Bank, PLC, 138 S. Ct. 1386 (2018).

4 Nestlé USA, Inc. v. Doe, 141 S. Ct. 188 (2020). The case has been granted certiorari before the Supreme Court on the question of corporate liability. Oral argument took place on Dec. 1, 2020. Commentary about the oral argument is cautiously optimistic for the plaintiffs. See Beth Van Schaack, Nestlé \& Cargill v. Doe Series: In Oral Arguments, Justices Weigh Liability for Chocolate Companies, JUST SEC. (Dec. 7, 2020), https://www.justsecurity.org/73727/nestle-cargill-v-doeseries-in-oral-arguments-justices-weigh-liability-for-chocolate-companies/

[https://perma.cc/XHF8-C3MK]. For a discussion of corporate liability under the ATS, see Doug Cassel, Corporate Aiding and Abetting of Human Rights Violations: Confusion in the Courts, 6 NW. J. INT'L HUM. RTS. 304 (2008) and William S. Dodge, Corporate Liability Under Customary International Law, 43 GEO. J. INT'L. L. 1045 (2012).

5 See Vedanta Resources PLC v. Lungowe [2019] UKSC 20 (Eng.) (affirming Lungowe v. Vedanta Resources PLC [2017] EWCA (Civ) 1528 and Lungowe v. Vedanta Resources PLC [2016] EWHC 975 (TCC)). See also Tara Van Ho, Vedanta Resources PLC and Another v. Lungowe and Others, 114 AM. J. INT'L. L 110 (2020); Dalia Palombo, The Duty of Care of the Parent Company: A Comparison between French Law, UK Precedents and the Swiss Proposals, 4 Bus. \& HuM. RTS. J. 265 (2019). 
overseas subsidiaries. ${ }^{6}$ The result of this case, Lungowe $v$. Vedanta Resources, is that plaintiffs in transnational business and human rights litigation have a stronger foundation on which to build their tort claims for damages against parent companies. The decision was unanimously reaffirmed by the U.K. Supreme Court in a second case, Okpabi v. Royal Dutch Shell PLC. ${ }^{7}$ The legal argument for direct parent company liability used in Lungowe and Okpabi has been applied in other European countries ${ }^{8}$ and common law jurisdictions, ${ }^{9}$ demonstrating that the U.K. precedent is having an echo effect on international jurisprudence. That effect has not yet been felt in the United States, however.

The current dichotomy between the United States and the United Kingdom ${ }^{10}$ has prompted consideration of the following: are the prospects for transnational business and human rights litigation in the United States as diminished as commentators portray them to be? Is there anything that can be drawn from the U.K. experience to improve access to remedy in the U.S. courts for victims of human rights violations at the hands of corporate actors? In answering these questions, this Article argues that expanding the circumstances in which a common law duty of care is imposed on a parent company for harm that occurs through its overseas operations is vital to enable victims to vindicate their rights against one of the actors that caused them harm.

Direct parent company liability is the key to achieving this vindication. By acknowledging the multiple ways in which the

6 The U.K. is divided into four separate legal jurisdictions, one of which is England and Wales. For the purposes of this Article, only this jurisdiction will be considered and references to England and the English courts shall be deemed to include Wales and Welsh courts.

7 Okpabi v. Royal Dutch Shell PLC [2021] UKSC 3 (overturning Okpabi v. Royal Dutch Shell PLC [2018] EWCA (Civ) 191 and Okpabi v. Royal Dutch Shell PLC [2017] EWHC 89 (TCC)).

8 See, e.g., Rb. Den Haag 30 januari 2013, JOR 2013, 162 m.nt. JF (Akpan/Royal Dutch Shell PLC) (Neth.); Hof's-Den Haag 18 december 2015, NJF 2015, 3857 m.nt. F.C.S. Warendorf (Akpan/Royal Dutch Shell PLC) (Neth.); Hof's-Den Haag 29 januari 2021, NJ 2021, 77 m.nt. (Milieudefensie/Shell Petroleum NV) (Neth.).

9 See, e.g., Choc v. Hudbay Minerals, Inc., [2013] ONSC 1414 (Can. Ont. Sup. Ct. J.).

10 The difference between the two pivotal decisions from the United States and the United Kingdom, Kiobel and Lungowe, respectively, has been described as "night and day." See Doug Cassel, Vedanta v. Lungowe Symposium: Beyond Vedanta-Reconciling Tort Law with International Human Rights Norms, OPINIO JURIS (Apr. 19, 2019), http://opiniojuris.org/2019/04/19/vedanta-v-lungowesymposium-beyond-vedanta-reconciling-tort-law-with-international-human-right s-norms \%EF\%BB\%BF/ [https://perma.cc/43A5-EXFB]. 
relationship between parent and subsidiary companies is conducted in a modern global enterprise, and attributing liability for intervention on the parent's part that has been instrumental in the harm the plaintiffs have suffered, the direct liability approach not only opens up the possibility of substantive parent company liability, but also connects the allegations in the case to the U.S. territory by focusing on the culpable actions or omissions of the U.S. parent company that occur at the headquarter level. This provides a counterpoint to the forum non conveniens defense and to concerns about infringement on host state sovereignty which infuse the recent ATS case law. Moreover, the relative success of the direct liability argument and the receptiveness of the courts in the United Kingdom and other jurisdictions to these claims ${ }^{11}$ may be a powerful argument to counter the unease about jurisdictional overreach that underlies recent Supreme Court decisions. ${ }^{12}$

The Article is organized in five parts. Part II traces the global trend in growth of transnational business and human rights litigation, noting the hurdles to bringing such cases, and highlighting the particular challenge presented by the corporate veil. Part III explores the current status of transnational business and human rights litigation in both federal and state courts. It briefly outlines the history of ATS claims, identifying the legal hurdles to their success. It considers the parallel conventional tort litigation trend both pre and post Kiobel, asking whether, in the period since Kiobel, the predicted wave of state tort litigation has materialized, ${ }^{13}$ and identifying legal hurdles to success in such cases. Turning the focus to the role of the corporate veil, Part III also discusses how liability is attributed to the parent company in transnational business and human rights litigation in the United States and, in particular, the test of agency. In Part IV, the case analysis turns to England. This has been the primary venue for transnational business and human rights litigation outside the

\footnotetext{
11 See, e.g., Nevsun Resources Ltd. v. Araya (2020), 443 D.L.R. 4th 183 (Can.) (holding that a claim for customary international law violations could proceed to trial before the Canadian courts).

12 See Kiobel v. Royal Dutch Petroleum Co., 569 U.S. 108 (2013); Daimler AG v. Bauman, 571 U.S. 117 (2014); Jesner v. Arab Bank, PLC, 138 S. Ct. 1386 (2018).

13 See generally Roger P. Alford, Human Rights After Kiobel: Choice of Law and the Rise of Transnational Tort Litigation, 63 EMORY L.J. 1089 (2014) (arguing that the most likely avenue for plaintiffs post Kiobel will be pleading violations of state or foreign tort laws).
} 
United States, ${ }^{14}$ although Canada may possibly surpass it after the recent Nevsun Resources Ltd. $v$. Araya ruling by the Supreme Court of Canada. ${ }^{15}$ The focus here is on the development of direct liability for the tort of negligence as a means of attributing liability to the parent company, and the application of the test. Part V draws together examples from other common law and civil law jurisdictions where the direct liability argument has been used in tort litigation, to demonstrate the uptake and development of the legal principle internationally. Part VI compares the agency approach adopted by courts in the United States with the direct liability approach taken in the United Kingdom and considers what lessons for the United States can be drawn from the English litigation. It concludes that the argument used in the U.K. case law to attribute liability directly to parent companies should be taken up in the United States.

14 See Michael D. Goldhaber, Corporate Human Rights Litigation in Non-U.S. Courts: A Comparative Scorecard, 3 U.C. IRvINE L. REV. 127, 127-28 (2013); Astrid Sanders, The Impact of the 'Ruggie Framework' and the 'United Nations Guiding Principles on Business and Human Rights' on Transnational Human Rights Litigation, in THE Business AND HuMAN RIGHTS LANDSCAPE: MOVING FORWARD, LOOKING BACK 288, 290 (Jena Martin \& Karen Bravo eds., 2015); see also Trevor C. Hartley, INTERNATIONAL COMMERCIAL LITIGATION: TEXT, CASES AND MATERIALS ON PRIVATE INTERNATIONAL LAW 310 (2009) (discussing the advantages of bringing legal proceedings in the English courts); Jonathan Watts, BHP Billiton Facing £5bn Lawsuit from Brazilian Victims of Dam Disaster, GuARDIAN (Nov. 6, 2018), https://www.theguardian.com/environment/2018/nov/06/bhp-billiton-facing5bn-lawsuit-from-brazilian-victims-of-dam-disaster [https://perma.cc/XYZ8E42P] (detailing cases against BHP Billiton for a dam disaster in Brazil); Município de Mariana v. BHP Group PLC [2020] EWHC 2930 (TCC); John Vidal, 'Mollah's Life was Typical': The Deadly Ship Graveyards of Bangladesh, GUARDIAN (Jan. 31, 2020), https://www.theguardian.com/global-development/2020/jan/31/khalid-molla h-life-was-typical-the-deadly-ship-graveyards-of-bangladesh?CMP=Share_iOSAp p_Other [https://perma.cc/T6QE-GUVR] (describing litigation against shipping company Maran for the death of a ship breaker in Bangladesh); Hamida Begum v. Maran (UK) Ltd [2020] EWHC 1846 (QB); Hamida Begum v. Maran (UK) Ltd [2021] EWHC Civ 326; Tanzanian Victims Commence Legal Action in UK against Barrick (Feb. 10, 2020), https://www.raid-uk.org/blog/tanzanian-victims-commence-legalaction-uk-against-barrick [https://perma.cc/2RBF-ZUUX] (regarding litigation against Barrick Tz alleging serious abuses by security forces in Tanzania); Kate Hodal, Petra Diamonds Pays $£ 4.3 \mathrm{~m}$ to Tanzanians 'Abused' by its Contractors, GUARDIAN (May 18, 2021), https://www.theguardian.com/global-development/2021/may/18/petra-diamo nds-pays-43m-to-tanzanians-abused-by-its-contractors [https://perma.cc/5D5]X58A]; Sarah Boseley, Tobacco Firms in Move to Strike out Malawi Exploitation Case, GUARDIAN (May 19, 2021) https:/ / www.theguardian.com/business/2021/may/19/tobacco-firms-in-moveto-strike-out-malawi-exploitation-case [https://perma.cc/4HVG-JX44].

15 Nevsun Resources Ltd. v. Araya (2020), 443 D.L.R. 4th 183 (Can.). 


\section{BARRIERS TO TRANSNATIONAL BUSINESS AND HUMAN RIGHTS LITIGATION: THE ROLE OF THE CORPORATE VEIL}

This Part introduces transnational business and human rights litigation and the role of the corporate veil as an impediment to plaintiffs bringing such cases.

\section{a. Business and Human Rights Litigation: The Global Picture}

A number of jurisdictions have developed a body of jurisprudence, which, to varying degrees, allows their courts to accept jurisdiction over claims where extraterritorial human rights violations committed by or in conjunction with corporate actors are framed as tort lawsuits and brought against a parent company in its home state. ${ }^{16}$ The development of this body of jurisprudence dates back to the 1980s when one of the original transnational tort claims was brought in U.S. courts following the catastrophic chemical leak at Bhopal in India. ${ }^{17}$ The American parent company, Union Carbide, was alleged to be liable in tort on the grounds that it exercised extensive control over its Indian subsidiary, the operator of the pesticides plant in Bhopal from where the chemicals leaked, killing and injuring tens of thousands of people. ${ }^{18}$ That control was evidenced, for instance, by the parent company's involvement in key decisions regarding plant design and safety. ${ }^{19}$ The U.S. courts' dismissal of the case on grounds that India was the appropriate

16 The term "home state" in relation to a multinational group of companies is used to denote the state in which the parent company is a corporate national. From a commercial, but not necessarily legal, perspective, this is the place where the group is headquartered or where the relevant decisions about actions in the host state are taken. The term "host state" refers to any state other than the home state in which that group operates or invests, or which is a significant source of goods or services for the group or its constituent companies.

17 In re Union Carbide Corp. Gas Plant Disaster at Bhopal, India in Dec., 1984, 634 F. Supp. 842 (S.D.N.Y. 1986), aff'd, 809 F.2d 195 (2d Cir. 1987), cert. denied, 108 U.S. 199 (1987).

18 Id. at 844.

19 AMNESTY INT'L, INJUSTICE INCORPORATED: CORPORATE ABUSES AND THE HumAN RigHT TO REMEDY 33-37 (2014). 
forum for the litigation, ${ }^{20}$ and the subsequent low value settlement of all proceedings against the corporate group by the Government of India, ${ }^{21}$ highlighted how difficult it is for victims in transnational business and human rights litigation to get access to remedy. The gravity of the injustice for the victims of Bhopal fomented the emerging international movement that demanded corporate accountability for extraterritorial harms. ${ }^{22}$

In the years that followed the initiation of the Bhopal litigation, a number of tort claims were brought before U.S. - mainly federal courts ${ }^{23}$ against American parent companies regarding the overseas operations of their subsidiaries. ${ }^{24}$ From the 1990s onwards, the federal ATS became the most common cause of action for plaintiffs bringing suit against corporations for alleged human rights violations overseas. Conventional tort claims were sometimes brought in parallel with ATS claims. ${ }^{25}$ During this period, tort cases were also initiated against corporate defendants in England and Wales, ${ }^{26}$ Canada, ${ }^{27}$ and Australia. ${ }^{28}$ With no statutory equivalent to the ATS, these cases in other common law countries were framed as conventional tort claims, and were dwarfed in number by the ATS claims. ${ }^{29}$ In recent years, since the U.S. Supreme Court cut back the

20 In re Union Carbide, 634 F. Supp at 866.

21 AMNESTY INT'L, supra note 19, at 48-53.

22 The litigation about Bhopal against Union Carbide and its successor company Dow continues to this day. See id. at 33-63; Anita Ramasastry, Corporate Social Responsibility Versus Business and Human Rights: Bridging the Gap Between Responsibility and Accountability, 14 J. HuM. RTs. 237, 240 (2015); Surya Deva, Bhopal: The Sage Continues 31 Years On, in Business AND HuMAN RIGHTS: FrOM PRINCIPLES TO PRACTICE 24 (Dorothée Baumann-Pauly \& Justine Nolan eds., 2014).

23 Filing in federal district courts is under the diversity jurisdiction set out in U.S. CONST. art. III, § 2 .

24 See, e.g., Aguinda v. Texaco, Inc., 142 F. Supp. 2d 534 (S.D.N.Y. 2001), aff'd, 303 F.3d 470 (2d Cir. 2002) (filed in 1993).

25 The difference between the two is that the ATS claims allege violations of customary international law norms, while the conventional tort claims allege federal or state torts as grounds for liability. See, e.g., Doe I v. Unocal Corp., 395 F.3d 932 (9th Cir. 2002), vacated and remanded, 403 F.3d 708 (9th Cir. 2005).

26 Connelly v. RTZ Corp. [1998] A.C. 854 (HL); Sithole v. Thor Chem. Holdings, Ltd. [1999] EWCA (Civ) 706; Lubbe v. Cape PLC [2000] UKHL 41 (HL).

27 Recherches Internationales Québec v. Cambior Inc., 1998 CarswellQue 1430 (Can. Que. Sup. Ct.).

28 Dagi v Broken Hill Proprietary Co. Ltd. (1997) 1 VR 428 (Austl.).

29 Andrew Sanger, Corporations and Transnational Litigation: Comparing Kiobel with the Jurisprudence of English Courts, 107 AM. J. INT'L. L UNBOUND 23 (2014); Peter Muchlinski \& Virginie Rouas, Foreign Direct-Liability Litigation: Towards the 
scope of the ATS in Kiobel v. Royal Dutch Petroleum Co. ${ }^{30}$ and Jesner v. Arab Bank, ${ }^{31}$ there has been renewed interest among the academy in common law tort claims as a vehicle for this litigation. ${ }^{32}$ Some scholars have looked to non-U.S. experience of such claims as offering a way forward for business and human rights litigation. ${ }^{33}$ There are a number of challenges that plaintiffs in these conventional tort claims must overcome, however.

\section{b. The Corporate Veil}

Three separate but interlocked veils operate to shield parent companies from liability in transnational business and human rights claims, namely: the corporate veil, the contractual veil, and the jurisdictional veil. ${ }^{34}$ With the corporate veil, the issue is how to attribute liability to the parent company when it has some direct knowledge and level of involvement in the misconduct, but the proximate cause of the harm is the subsidiary company's actions. ${ }^{35}$

Transnationalization of Corporate Legal Responsibility, in CORPORATE RESPONSIBILITY FOR HuMAN RIGHTS IMPACTS: NEW EXPECTATIONS AND PARADIGMS 357 (Lara Blecher et al. eds., 2014); Richard Meeran, Tort Litigation Against Multinational Corporations for Violation of Human Rights: An Overview of the Position Outside the United States, 3 CitY U. H.K.L. REV. 1 (2011); SARAH JOSEPH, CORPORATIONS AND TRANSNATIONAL HUMAN RigHTS LITIGATION (2004).

30569 U.S. 108 (2013).

31 138 S. Ct. 1386 (2018) (discussed further in Part III); see also Daimler AG v. Bauman, 571 U.S. 117 (2014).

32 Roger P. Alford, for example, argues, "[t]he most important alternative avenue [to the ATS] is tort law. Indeed, one could say that the future of human rights litigation in the United States depends on refashioning human rights claims as state or foreign tort violations." Roger P. Alford, The Future of Human Rights Litigation After Kiobel, 89 Notre Dame L. ReV. 1749, 1749-50 (2014). For other examples, see infra note 113.

33 Goldhaber, supra note 14, at 128; see also Jodie A. Kirshner, A Call for the EU to Assume Jurisdiction over Extraterritorial Corporate Human Rights Abuses, 13 Nw. J. INT'L Hum. RTs. 1, 17 (2015); Doug Cassel, Outlining the Case for a Common Law Duty of Care of Business to Exercise Human Rights Due Diligence, 1 Bus. \& HuM. RTs. J. 179 (2016).

34 See Peter Muchlinski, Limited Liability and Multinational Enterprises: A Case for Reform?, 34 CAMBRIDGE J. ECON. 915, 920 (2010) (introducing the concept of the jurisdictional veil).

35 Attributing liability to parent companies in transnational tort litigation is the subject of numerous scholarly works. Foundational contributions from Phillip I. Blumberg on corporate groups and the drawbacks of limited liability form the backdrop to the discussion in this Article. See Phillip I. Blumberg, Limited Liability and Corporate Groups, 11 J. CORP. L. 573 (1986). 
The long-established corporate law principles of the corporate veil, separate personality, and limited liability operate to prevent the parent corporation from being liable for the subsidiary's wrongdoing. With the contractual veil, in circumstances where the relationship is not one of equity but rather one of contract between the parent (also called "lead") company and its suppliers, the separate personalities of the corporations and the terms of their contractual relationship prevent the parent company from being liable for the supplier's wrongdoing. With the jurisdictional veil, the territorial sovereignty principle from public international law gives the host state authority to prescribe rules governing people and events on its territory, and to adjudicate related disputes. A corollary of territorial sovereignty is the jurisdictional veil, which limits the home state's power to exercise its legal authority extraterritorially in order to prescribe rules and adjudicate disputes when harm occurs in the host state. While all three veils act to shield parent companies from liability when harm occurs ostensibly at the hands of a subsidiary or supplier, it is the corporate veil that is the focus here. Positive case law developments outside the United States - which have triggered the authorship of this Article-have helped to lessen the strictures of the corporate veil. ${ }^{36}$ The role of the jurisdictional veil as an impediment to plaintiffs' success in transnational business and human rights litigation against parent companies will be touched on, as well, given its significance as a hurdle to plaintiffs in U.S. litigation exemplified in cases dismissed on grounds of forum non conveniens or the presumption against extraterritoriality.

The basic premise of the corporate veil was set out by the U.S. Supreme Court in United States v. Bestfoods, "[i]t is a general principle of corporate law deeply ingrained in our economic and legal systems' that a parent corporation ... is not liable for the acts of its subsidiaries." 37 "The doctrine of limited liability holds that, in principle, the shareholders in a business may not be held liable for

36 It has been argued that direct liability can also be applicable when companies are divided by the contractual veil. See Landgericht Dortmund [Dortmund District Court] Jan. 10, 2019, 7 O 95/15, Justiz-online (Ger.) http://www.justiz.nrw.de/nrwe/lgs/dortmund/lg_dortmund/j2019/7_O_95_1 5_Urteil_20190110.html [https://perma.cc/FQP5-JJKE]; see also infra Part V. The focus here is primarily on companies linked by equity.

37524 U.S. 51, 61 (1998) (quoting William O. Douglas \& Carrol M. Shanks, Insulation from Liability through Subsidiary Corporations, 39 Yale L.J. 193, 193 (1929)). 
the debts of that business beyond the level of their investment." 38 The related doctrine of separate personality holds that the legal personality of one business is distinct from the legal personality of another business, separating them by a corporate veil, regardless of the links of ownership and/or control between them.

Historically, limited liability existed to encourage economic growth by protecting entrepreneurs so that they could invest in businesses without fear of personal liability. But, as Phillip Blumberg famously noted, the concept of limited liability originates from a time when corporations were not generally allowed to hold shares in other corporations, meaning that the parent-subsidiary relationship did not exist. ${ }^{39}$ The use of the corporate veil to shield parent companies from liability for the debts of their subsidiaries in corporate groups "opens the door to multiple layers of insulation [from liability], a consequence unforeseen when limited liability was [first] adopted." 40 It also belies the links of strategy, control and other forms of intervention that connect the different companies in a corporate group and that are recognized economically and politically, ${ }^{41}$ provoking some scholars to advocate for wholesale reform of limited liability in human rights cases against corporations. ${ }^{42}$

38 GWynne SKinner, Robert McCorquodale \& Olivier De Schutter, The

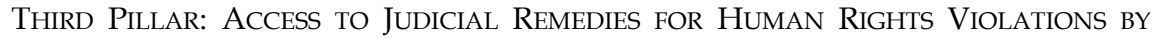
TRANSNATIONAL BUSINESS 57 (2013) (citing Anderson v. Abbott, 321 U.S. 349, 361-62 (1944)).

39 Phillip I. Blumberg, Accountability of Multinational Corporations: The Barriers Presented by Concepts of the Corporate Juridical Entity, 24 HASTINGS INT'L \& COMP. L. REV. 297, 300-04 (2001).

40 Phillip I. Blumberg, The Multinational Challenge to Corporation LaW: The SEARCH For A New Corporate Personality 139 (1993).

41 Blumberg, supra note 39, at 303. Ironically, empirical studies have shown that courts are less likely to pierce the corporate veil to expose the corporate shareholders in corporate groups, as opposed to individual shareholders. See Robert B. Thompson, Piercing the Corporate Veil: An Empirical Study, 76 CoRnell L. REV. 1036, 1038 (1991).

42 See Gwynne Skinner, Rethinking Limited Liability of Parent Corporations for Foreign Subsidiaries' Violations of International Human Rights Law, 72 WASH. \& LEE L. REV. 1769 (2015); Anil Yilmaz Vastardis \& Rachel Chambers, Overcoming the Corporate Veil Challenge: Could Investment Law Inspire the Proposed Business and Human Rights Treaty?, 67 INT'L \& COMP. L.Q. 389 (2018). To address this problem, Skinner proposed a new statute-based model that would allow courts to disregard limited liability of parent corporations for claims of customary international human rights violations and serious environmental torts, where a parent corporation takes a majority interest or creates a subsidiary as part of a unified economic enterprise that operates in a "high-risk host country." See GWYNNE SKINNER, PARENT COMPANY ACCOUNTABILITY: ENSURING JUSTICE FOR HUMAN RigHTS ViOLATIONS 24 (2015). 
There are various techniques that plaintiffs in tort litigation may adopt to attribute liability to the parent company when it has some direct knowledge and some level of involvement in the subsidiary's alleged wrongdoing. ${ }^{43}$ The first option is to seek to pierce the corporate veil and make the parent company liable for the negligence of its subsidiary. Tests vary for veil piercing, but in most jurisdictions this power is reserved for exceptional cases only. ${ }^{44}$ In the United States, there are different tests applied in different states. But, generally speaking, the corporate veil can only be pierced when the parent "misuses the separate corporate form for wrongful purposes and controls the subsidiary to the extent that the subsidiary is a mere instrument of the parent." 45 Scholars have documented that veil-piercing tests are vague and inconsistently applied by the courts. ${ }^{46}$ Plaintiffs therefore use other methods to attribute liability to the parent company: in particular they allege that the subsidiary acted as an agent for the parent company in the particular action that gave rise to the claim. ${ }^{47}$

As discussed below, ${ }^{48}$ establishing agency is a significant hurdle for plaintiffs to surmount, although not as difficult as veil piercing. Another technique that has been used in tort cases in common law countries outside the United States is to allege that the parent company is directly liable for harm in respect of its own primary breach of duty, based on the parent owing its own duty of care to the plaintiffs. This theory, sometimes referred to as "foreign direct liability," 49 holds that "when a parent company is directly involved [to a sufficient degree] in its subsidiary's operations or exercises de

43 This Article does not address the problem identified by Skinner of "victims left without a remedy where the parent has a more separate relationship from the subsidiary but still greatly benefits financially from the fact that it created a subsidiary in a high-risk environment." Skinner, supra note 42, at 1841.

44 Thompson, supra note 41, at 1044-45. Frequently the veil will only be pierced "where there has been fraud or where the level of control by the parent company is so extreme as to render the corporation an alter ego or a sham." Vastardis \& Chambers, supra note 42, at 394-95. In English case law, an example of this strict approach is Adams v. Cape Industries PLC [1989] AC 433 (appeal taken from EWHC (Ch)) (Eng.).

45 Skinner, supra note 42, at 1797.

46 Id. at 1798.

47 Bowoto v. Chevron Texaco Corp., 312 F. Supp. 2d 1229 (N.D. Cal. 2004).

48 See generally infra Part III (discussing agency).

49 See generally Liesbeth Enneking, The Future of Foreign Direct Liability? Exploring the International Relevance of the Dutch Shell Nigeria Case, UTRECHT L. REV., Jan. 2014, at 44 (charting the international trend of foreign direct liability cases and the Dutch Shell Nigeria case's status as part of that trend). 
facto control, then it owes a duty of care to its employees or anyone affected by its [subsidiary's] operations ... [and] may be held liable for harm flowing from its failure to competently perform the functions" of its involvement. ${ }^{50}$ The development of direct liability in case law is addressed in Parts III and IV below.

\section{c. Arguments in Favor of Parent Company Liability}

Attributing liability to the parent company allows plaintiffs to bring within the frame of judicial consideration the parent's acts of supervision, management, and control of the subsidiary, which may have been instrumental in the harm the plaintiffs have suffered, ostensibly at the hands of the subsidiary. Furthermore, plaintiffs can sue the parent company in the home state, its incorporation there providing the required connection to the jurisdiction to enable the home state courts to hear the claim, in accordance with the relevant rules of domestic private international law. ${ }^{51}$ The necessity for plaintiffs to have access to remedy in the courts of the home state of the parent company as a result of the widely acknowledged governance gap in corporate accountability is well covered in the literature. ${ }^{52}$ In some instances, this is the only option for them when host state remedies are absent or ineffective due to corruption, weakness or absence of the rule of law, lack of financial resources to enforce local laws, hold timely trials, etc. ${ }^{53}$ Accessing remedy in home state courts also avoids plaintiffs having to seek compensation from a local subsidiary, which may be impecunious or defunct.

50 Goldhaber, supra note 14 , at 132.

51 The relevant cases on personal jurisdiction over corporate defendants are Goodyear Dunlop Tires Operations, S.A. v. Brown, 564 U.S. 915 (2011) and Daimler AG v. Bauman, 571 U.S. 117 (2014). For European Union states, jurisdiction is governed by the Brussels Regulation recast, Council Regulation (EU) 1215/2012 on jurisdiction and the recognition and enforcement of judgments in civil and commercial matters. 2012 O.J. (L 351/1) art. 4 [hereinafter Brussels Regulation].

52 See, e.g., Penelope Simons \& Audrey Macklin, The Governance Gap: EXtRactive Industries, Human Rights, AND tHe Home State AdVANTAGE (2014).

53 The flow of foreign direct investment (FDI) from around the mid twentieth century onwards has been from industrialized countries of the Global North to developing countries of the Global South. Although this pattern is changing, with the result that "host state" is no longer synonymous with "developing country," this Article takes as its focus host countries of the Global South which may exhibit the access to remedy problems listed here. 
The normative justification for holding a parent company accountable for its negligent involvement in the harmful operations of its subsidiary is compelling. ${ }^{54}$ The ability of parent companies to exert influence and control across the whole corporate group while retaining legal separation from the entities that comprise the rest of the group makes transnational business uniquely able to take advantage of the economic and regulatory reality of the globalized world in which it operates. ${ }^{55}$ For example, it allows parent companies to structure their liability risk by sometimes undercapitalizing their foreign subsidiaries that might be the target for claims due to the nature of the activities they undertake, or due to the lower social or environmental standards adopted by business in many developing host states, ${ }^{56}$ while at the same time often "reap[ing] large economic benefits from these [] subsidiaries." 57

John Ruggie, the architect of the current international policy consensus in this area - the UN Guiding Principles on Business and Human Rights ("UNGPs") ${ }^{58}$ - explicitly recognized the role of tort law in providing access to remedy to victims of human rights abuse at the hands of corporations, 59 and urged states to address the difficulties created by the corporate veil. Without making this a legal obligation, the UNGPs tell states that in extraterritorial cases

54 See SKINNER, supra note 42.

55 Peter Muchlinski, Multinational Enterprises AND the LaW 5-8 (2d ed. 2007); Janet Dine, Companies, International Trade, AND Human Rights 43-53 (2005).

56 The double standards practice of transnational business in relation to environmental standards has been documented in at least two U.N. studies, surveying businesses adopting lower environmental standards in the surveyed developing countries than those adopted in developed countries. See Tetsuya Morimoto, Research Paper, Growing Industrialization and our Damaged Planet: The Extraterritorial Application of Developed Countries' Domestic Environmental Laws to Transnational Corporations Abroad, UTRECHT L. REV., DEC. 2005, AT 134, 137.

57 Vivian Grosswald Curran, Harmonizing Multinational Parent Company Liability for Foreign Subsidiary Human Rights Violations, 17 CHI. J. INT'L. L. 403, 411 (2016).

58 Human Rights Council, Rep. of the Special Representative of the SecretaryGeneral on the Issue of Human Rights and Transnational Corporations and other Business Enterprises, John Ruggie, Guiding Principles on Business and Human Rights: Implementing the United Nations "Protect, Respect and Remedy" Framework, U.N. Doc. A/HRC/17/31, annex (Mar. 21, 2011) [hereinafter UNGPs].

59 Human Rights Council, Rep. of the Special Representative of the SecretaryGeneral on the Issue of Human Rights and Transnational Corporations and other Business Enterprises, John Ruggie, Business and Human Rights: Mapping International Standards of Responsibility and Accountability for Corporate Acts, U.N. Doc. A/HRC/4/35 (Feb. 9, 2007). 
they should consider ways to reduce the barriers that could lead to a denial of access to remedy. ${ }^{60}$ Such barriers include " $[t]$ he way in which legal responsibility is attributed among members of a corporate group" in a way that facilitates the "avoidance of appropriate accountability." 61 Despite this recognition, and the unanimous endorsement of the UNGPs by the U.N. Human Rights Council, ${ }^{62}$ it remains the position that access to remedy is the most neglected of the three UNGP pillars, ${ }^{63}$ and the global pattern is that victims of business-related human rights abuse in extraterritorial cases do not generally have access to effective remedies. ${ }^{64}$ One of the key reasons for this is the difficulty tort plaintiffs have in attributing liability to parent companies because of the corporate veil. 65

\section{TRANSNATIONAL BUSINESS AND HUMAN RIGHTS LITIGATION IN THE UNITED STATES}

This Part begins with a summary of the legal history and current status of ATS and conventional tort litigation in the United States, which grounds the analysis of whether prospects for such cases are as diminished as commentators portray them to be. ${ }^{66}$ It explores the reasons why courts have dismissed the majority of such claims and the role of the corporate veil as a hurdle to plaintiffs. This Part examines how plaintiffs seek to attribute liability to the parent company in transnational business and human rights litigation,

60 UNGPs, supra note 58, at 23.

61 Id. Another barrier is " $[\mathrm{w}]$ here claimants face a denial of justice in a host State and cannot access home State courts regardless of the merits of the claim." Id.

62 State membership of the Human Rights Council at the time included the United Kingdom and the United States. Membership of the Human Rights Council 19 June 2010 - 18 June 2011 by Year When Term Expires, UnITED NATIONS, https://www.ohchr.org/EN/HRBodies/HRC/Pages/Year20102011.aspx [https://perma.cc/BZ72-VJ6G].

63 The other pillars are the state duty to protect and the corporate responsibility to respect. UNGPs, supra note 58 , at 4 .

64 Cassel, supra note 33, at 182.

65 Skinner, supra note 42, at 1804 n.120; SKInNER, MCCorQuOdale \& DE SCHUTTER, supra note 38, at 56-59.

66 A comprehensive review of the history of ATS litigation is beyond the scope of this Article. For an overall history and analysis of ATS cases, see Beth Stephens, The Curious History of the Alien Tort Statute, 89 NOTRE DAME L. REV. 1467 (2014) and Beth Stephens, The Rise and Fall of the Alien Tort Statute, in RESEARCH HANDBOOK ON HumAn Rights AND Business 46 (Surya Deva \& David Birchall eds., 2020). 
using an emblematic example, Acuña-Atalaya v. Newmont Mining Corporation. ${ }^{67}$ There follows, in Part VI, a comparison of the relevant law in the United States and the United Kingdom, and recommendations for U.S. courts.

\section{a. The ATS: The Rise and Fall of the Statute}

The United States, through the ATS, was the dominant jurisdiction in the field of transnational business and human rights litigation for a number of years. Already the subject of voluminous scholarship, the ATS of 1789 grants district courts original jurisdiction over "any civil action by an alien for a tort only, committed in violation of the law of nations or a treaty of the United States." 68 Thus, and uniquely so, it links public international law to tort law. In the landmark case of Filártiga v. Peña-Irala, ${ }^{69}$ the "flagrant disregard of basic human rights and particularly the right to be free of torture" was found to be actionable under the ATS, ushering in a new era of human rights litigation. ${ }^{70}$ In 1997, in a case concerning alleged corporate complicity in serious human rights violations including forced labor, extrajudicial killings, torture, and rape suffered by the plaintiffs at the hands of the Burmese military in connection with the construction of a natural gas pipeline in Burma, it was held for the first time that the courts have authority to adjudicate claims against corporations and their executive officers under the ATS, and that corporations and their executive officers could be held liable for violating norms of customary international law. ${ }^{71}$ This litigation, Doe I $v$. Unocal Corp., marked the beginning of

67308 F. Supp. 3d 812 (D. Del. 2018), vacated and remanded, 765 F. App'x 811 (3d Cir. 2019).

68 Alien's Action for Tort, 28 U.S.C. § 1350.

69630 F.2d 876 (2d Cir. 1980).

70 Id. at 890 .

71 Doe I v. Unocal Corp., 395 F.3d 978 (9th Cir. 2003). Note that when this question came before the U.S. Court of Appeals for the Second Circuit, in Kiobel v. Royal Dutch Petroleum Co., 621 F.3d 111 (2d Cir. 2010), the court dismissed the claim because it interpreted customary international law as being inapplicable to corporations. The decision was the subject of an appeal to the Supreme Court which went on to address a different question, namely whether courts may recognize causes of action for violations of international law within the territory of a country other than the U.S. In Jesner v. Arab Bank, PLC, 138 S. Ct. 1386 (2018), the Supreme Court was split on whether corporations can be liable under the ATS. 
a trend of suing corporations under the ATS that saw about 180 claims filed by $2013 .^{72}$

The contemporary use of the ATS was first reviewed by the Supreme Court not in a business and human rights case, but in litigation alleging the forcible abduction of a murder suspect: Sosa v. Alvarez-Machain. ${ }^{73}$ The judgment in Sosa, acknowledging foreign relations concerns that call for judicial restraint in ATS litigation, affirmed the recent ATS case law but emphasized, inter alia, that only a "narrow set of violations" - those "threatening serious consequences in international affairs" - could be invoked under the statute. ${ }^{74}$

When the Supreme Court reviewed the contemporary use of the ATS for a second time, in the business and human rights case Kiobel v. Royal Dutch Petroleum Co., it curtailed the reach of the statute dramatically. ${ }^{75}$ The corporate defendants, Royal Dutch Petroleum (the Anglo Dutch parent company) and Shell Petroleum Development Company (its Nigerian subsidiary), were accused of being instrumental in the actions of the Nigerian military against protesters in the Niger Delta. ${ }^{76}$ Violations of jus cogens were among the allegations. ${ }^{77}$ The case was rejected in the district court and on

72 For a full list of ATS cases where at least one defendant is a corporate entity, see Goldhaber, supra note 14, at 137-49 (list compiled by Jonathan Drimmer). For a breakdown of "where they are filed, against whom, and why," see Jonathan C. Drimmer \& Sarah R. Lamoree, Think Globally, Sue Locally: Trends and Out-of-Court Tactics in Transitional Tort Actions, 29 BERKELEY J. INT'L L. 456, 461-464 (2011).

73542 U.S. 692 (2004).

74 Id. at 715. The Court ruled that the ATS is a jurisdictional act, which does not create a cause of action based on customary international law but entitles plaintiffs to bring actions in court for the violation of customary international law on the basis of a common law cause of action in tort. Lower courts were urged to exercise "great caution" in cases that raised risks of adverse foreign policy consequences. Id. at 694 .

75569 U.S. 108 (2013); see Robert C. Bird, Daniel R. Cahoy \& Lucien J. Dhooge, Corporate Voluntarism and Liability for Human Rights in the Post-Kiobel World, 102 KY. L.J. 601 (2013). There was no challenge to personal jurisdiction. A companion case, Wiwa v. Royal Dutch Petroleum Co., No. 96 Civ. 8386, 2002 U.S. Dist. LEXIS 3293 (S.D.N.Y. Feb. 28, 2002), alleging similar facts but brought by different plaintiffs, had been successfully settled prior to Kiobel. In this litigation, the court accepted subject-matter jurisdiction over the majority of the claims and dismissed the defense of forum non conveniens. The federal court indicated in this preliminary decision that SPDC was the alter ego of the defendant parent corporation. JOSEPH, supra note 29 , at 130 .

76 Kiobel, 569 U.S. at 113.

77 Id. The Vienna Convention on the Law of Treaties defines a jus cogens norm as "a norm accepted and recognized by the international community of States as a 
appeal. It came to the Supreme Court following a decision of the U.S. Court of Appeals for the Second Circuit that corporations could not be held liable for violations of customary international law, and thus could not be sued under the ATS.78 Unexpectedly, however, the Supreme Court asked for additional argument on whether and in what circumstances the ATS could be applied to conduct outside the United States. ${ }^{79}$

The judgment turned on whether the presumption against extraterritoriality of federal statute-law based claims applied to the ATS and, if so, how it should be applied in the particular case. The majority opinion in the Court held that the principles that underlie the presumption against extraterritoriality should indeed apply under the ATS 80 because of "the danger of unwarranted judicial interference in the conduct of foreign policy." 81 The Court found nothing in the text of the ATS that evinced "the requisite clear indication of extraterritoriality." 82 The Court clarified, however, that, in some circumstances, a claim might have sufficient ties with the United States to dislodge the presumption. Where claims "touch and concern the territory of the United States... with sufficient force" they will "displace the presumption against extraterritorial application," even if they arise outside of the United States. ${ }^{83}$ This touch and concern standard was not met in Kiobel, however, in which violations occurred outside of U.S. territory and the corporate defendants were foreign too. The outcome of Kiobel came as a blow to corporate accountability advocates. Up until that point, most, if not all, ATS cases against corporate defendants concerned harmful events that occurred overseas. The decision in Kiobel that the principles underlying the presumption against extraterritoriality apply to the ATS therefore represented a sea-change in the

\footnotetext{
whole as a norm from which no derogation is permitted and which can be modified only by a subsequent norm of general international law having the same character." Vienna Convention on the Law of Treaties art. 53, May 23, 1969, 1155 U.N.T.S. 331 (entered into force Jan. 27, 1980).

78 Kiobel v. Royal Dutch Petroleum Co., 621 F.3d 111 (2d Cir. 2010).

79 Lyle Denniston, Kiobel to be Expanded and Reargued, SCOTUSblog (Mar. 5, 2012), https://www.scotusblog.com/2012/03/kiobel-to-be-reargued/ [https://perma.cc/S4Y5-PNSM].

80 Kiobel, 569 U.S. at 124-25.

81 Id. at 116.

82 Id. at 119.

83 Id. at $124-25$.
} 
interpretation of the statute, ${ }^{84}$ and provoked doomsday predictions about the future of ATS litigation. 85

Kiobel has not quite been the "death knell" to ATS human rights litigation that some predicted, however. 86 In the years since the decision, some courts-albeit a minority-have allowed ATS litigation to proceed, finding that the claims touch and concern the United States with sufficient force, ${ }^{87}$ but there has been inconsistency among the circuits in their application of the touch and concern test, resulting in different outcomes for plaintiffs. These applications vary from requiring that the alleged violations of customary international law took place in the United States, ${ }^{88}$ to a more fact-based inquiry looking at different aspects of the case including the citizenship of the defendants and potential U.S. national interests triggered by the nature of the defendants' conduct. ${ }^{89}$ Proving that the alleged violation of customary international law took place in the United States is very challenging for plaintiffs in transnational business and human rights litigation,

84 See Beth Stephens, Extraterritoriality and Human Rights After Kiobel, 28 MD. J. INT'L L. 256 (2013).

85 See Matteo M. Winkler, What Remains of the Alien Tort Statute after Kiobel, 39 N.C.J. INT'L L. \& COM. REG. 171, 172-173 (2013).

86 Id. at 172. An example of a case that was dismissed on the basis of Kiobel is Balintulo v. Daimler AG, 727 F.3d 174, 192 (2d Cir. 2013). See William S. Dodge, Business and Human Rights Litigation in U.S. Courts Before and After Kiobel, in Business AND HumAN Rights: FROM PRINCIPLES tO PRACTICE 244, 250 (Dorothée Baumann-Pauly \& Justine Nolan eds., 2016); Jennifer M. Green, The Rule of Law at a Crossroad: Enforcing Corporate Responsibility in International Investment Through the Alien Tort Statute, 35 U. PA. J. INT'L L. 1085 (2014). The Institute for Legal Reform tracks the status of ATS litigation against U.S. companies after the Supreme Court's Kiobel decision and reports that of forty cases that were pending at the time of Kiobel, only $13 \%$ have been allowed to proceed on the merits. See INSTITUTE FOR LEGAL REFORM, LAWSUITS Against CORPORATIONS Under THE ALIEN TORT STATUTE 3, https://www.instituteforlegalreform.com/uploads/sites/1/Lawsuits_Against_C orporations_Under_the_Alien_Tort_Statute_.pdf [https://perma.cc/R43Q-766G].

87 Dodge, supra note 86, at 250 (citing Al Shimari v. CACI Premier Tech., Inc., 758 F.3d 516 (4th Cir. 2014)); see also Doe I v. Nestlé, S.A., 748 F. Supp. 2d 1057 (C.D. Cal. 2010), vacated by 738 F.3d 1048 (9th Cir. 2013).

88 See Adhikari v. Kellogg Brown \& Root, Inc., 845 F.3d 184, $194-97$ (5th Cir. 2017).

89 See Doe v. Drummond Co., Inc., 782 F.3d 576, 595-96 (11th Cir. 2015) (describing the U.S. citizenship of defendants and the allegation that the defendants funded an organization designated by the Department of State as a Foreign Terrorist Organization as relevant to the "touch and concern" inquiry, but insufficient on their own to displace the presumption against extraterritoriality). 
but the more fact-based inquiry is a significant hurdle, too. ${ }^{90}$ Some respite for plaintiffs has come in a decision of the Ninth Circuit, which refined the requirement that the alleged violations of international law take place in the United States, holding that the "focus" of the ATS (a test from the case RJR Nabisco, Inc. v. European Cmty ${ }^{91}$ ) was not limited to the principal offenses but also to aiding and abetting. ${ }^{92}$

Other challenges for ATS plaintiffs have arisen. First, case law development in the law on personal jurisdiction over corporate defendants has had the effect of restricting the ability of plaintiffs to sue foreign corporations, impacting ATS cases in particular. ${ }^{93}$ Pursuant to these cases, in nearly all circumstances, a corporation must be headquartered or incorporated in the forum state to be sued there. ${ }^{94}$ This hurdle for plaintiffs was solidified in ATS cases with the prohibition against suing foreign corporations under this statute that was instituted in Jesner $v$. Arab Bank. ${ }^{95}$ Second, and of even greater concern to corporate accountability advocates, the question of whether corporations can be held liable for violations of customary international law resurfaced in Jesner. ${ }^{96}$ The Justices left this issue unresolved, leaving the door open to defendants to challenge corporate liability under the ATS in subsequent cases, ${ }^{97}$ with success on at least one occasion. 98 The Supreme Court recently heard argument on this question in the case of Nestlé USA, Inc. v. Doe $I, 99$ a class action claim by Malian child plaintiffs allegedly trafficked

90 See Warfaa v. Ali, 811 F.3d 653, 660 (4th Cir. 2016), cert. denied, 137 S. Ct. 2289 (2017); Al Shimari v. CACI Premier Tech., Inc., 758 F.3d 516, 528-29 (4th Cir. 2014).

91 136 S. Ct. 2090, 2101 (2016).

92 Doe I v. Nestlé, S.A., 906 F.3d 1120 (9th Cir. 2018), amended by 929 F.3d 623 (9th Cir. 2019). This decision is the subject of an appeal to the Supreme Court: Nestlé USA, Inc. v. Doe I, 141 S.Ct. 188 (2020).

93 See Gerlinde Berger-Walliser, Reconciling Transnational Jurisdiction: A Comparative Approach to Personal Jurisdiction over Foreign Corporate Defendants in U.S. Courts, 51 VAND. J. TRANSNAT'L. L. 1243 (2018); Gerlinde Berger-Walliser, Reforming International Human Rights Litigation against Corporate Defendants after Jesner v. Arab Bank, 21 U. PA. J. Bus. L. 757 (2019).

94 Daimler AG v. Bauman, 571 U.S. 117 (2014).

95138 S. Ct. 1386 (2018).

96 Id. at 1400; see William S. Dodge, Corporate Liability Under the US Alien Tort Statute: A Comment on Jesner v. Arab Bank, 4 Bus \& HuM. RTs. J. 131 (2019).

97 Id. at 1402. See Doe I v. Nestlé, S.A., 906 F.3d 1120 (9th Cir. 2018), amended by 929 F.3d 623 (9th Cir. 2019); Estate of Alvarez v. Johns Hopkins Univ., 275 F. Supp. 3d 670 (D. Md. 2017).

98 Doe I v. Exxon Mobil Corp., 391 F. Supp. $3 d 76$ (D.D.C. 2019).

$99 \quad 141$ S. Ct. 188 (2020). 
by cocoa growers into Côte D'Ivoire and forced to work in farms that supplied cocoa beans to defendants. ${ }^{100}$ The Trump Administration supported the defendant companies by arguing in an amicus brief that corporate liability is precluded under the ATS. ${ }^{101}$

The preceding paragraphs have described the hurdles that ATS plaintiffs now face. Even prior to the seismic changes brought about by the Supreme Court decisions, ATS cases faced significant challenges and were dismissed for a number of different reasons, 102 the corporate veil among them. ${ }^{103}$ In Sinaltrainal v. Coca Cola Co., 104 for instance, the district court rejected the plaintiffs' allegations of an agency relationship between Coca Cola USA and Coca Cola Colombia, its wholly owned subsidiary, and thus rejected the claim against the American company. Although the jurisdictional veil is now the most significant hurdle for plaintiffs, the focus on the wrongful actions of the U.S.-based parent company that the Supreme Court decisions require brings to the fore corporate veil questions as well, in particular how the parent company can be held liable in a given case. As with the direct liability line of cases, the parent's contribution to the overseas harm is under the spotlight. Before looking at the question of attributing liability to the parent company, the next section will track conventional tort litigation of business and human rights claims in the United States, the parallel trend to ATS litigation.

\footnotetext{
UNITED

https://www.supremecourt.gov/oral_arguments/audio/2020/19-416

[https://perma.cc/RPA5-CMQ7].

101 This was a reversal of the Trump administration's earlier position on this issue. See William S. Dodge, Trump Administration Reverses Position on Corporate Liability Under Alien Tort Statute, Just SEC. (June 1, 2020), https://www.justsecurity.org/70512/trump-administration-reverses-position-oncorporate-liability-under-alien-tort-statute [https://perma.cc/2QEC-6CA7].

102 David Nersessian describes how some cases were dismissed for reasons related to the jurisdictional veil, such as judicial comity. DAVID NERSESSIAN, INTERNATIONAL HUMAN RigHTS LiTIGATION: A GUIDE FOR JUDGES 112 (2016) ("Comity encompasses 'the spirit of cooperation in which a domestic tribunal approaches the resolution of cases touching the laws and interests of other sovereign states.'" (citing Société Nationale Industrielle Aérospatiale v. U.S. Dist. Court, 482 U.S. 522, 543 n. 27 (1987))).

103 Skinner, supra note 42, at 1804 n.120 (listing a number of such cases).

104578 F.3d 1252 (11th Cir. 2009).
}

100 Oral Argument - Audio: Nestlé USA, Inc. v. Doe, SUPREME COURT OF THE 


\section{b. Conventional Tort Litigation}

Since the 1990s, a number of conventional tort claims based on transitory tort theory ${ }^{105}$ have been brought before the U.S. federal and occasionally state courts against parent companies, seeking to attribute liability to them for harm that has occurred overseas through the operations of their subsidiaries. One of the earliest cases was the Bhopal litigation introduced above.106 The number of conventional tort claims increased with the ascendency of the ATS, as ATS cases routinely include parallel state law claims in the federal courts. ${ }^{107}$ Plaintiffs also sometimes present state law claims parallel to ATS litigation, but in state courts. In Doe I v. Unocal Corp., ${ }^{108}$ discussed above, ${ }^{109}$ the plaintiffs re-filed their pendent state law claim in the state court after the ATS claims were dismissed. The case settled prior to the start of the state court trial.110 In another such case, the plaintiffs sought damages in tort law for personal injuries suffered as a result of Chevron/Texaco's operations in the Niger Delta, in the federal court, in parallel with an ATS claim.111 In the period since the advent of ATS litigation against corporate defendants, conventional tort claims have also been filed without accompanying ATS claims, ${ }^{112}$ although this is a relatively infrequent occurrence. Not nearly as visible as ATS litigation in the academic literature, certain scholars, including Svetlana Nagiel, have commented on this trend of conventional tort litigation against

105 See, e.g., Chimène I. Keitner, State Courts and Transitory Torts in Transnational Human Rights Cases, 3 U.C. IRVINE L. REV. 81, 83-87 (2013).

106 In re Union Carbide Corp. Gas Plant Disaster at Bhopal, India in Dec., 1984, 634 F. Supp. 842 (S.D.N.Y. 1986), aff'd, 809 F.2d 195 (2d Cir. 1987).

107 See, e.g., Wiwa v. Royal Dutch Petroleum Co., 226 F.3d 88, 93-94 (2d Cir. 2000) (arising from the same set of facts as Kiobel and alleging both state and foreign tort law violations); Jonathan Drimmer, Resurrection Ecology and the Evolution of the Corporate Alien Tort Movement, 43 GEO. J. INT'L L. 989 (2012) (discussing the birth and rise of the corporate ATS movement).

108 See, e.g., Doe I v. Unocal Corp., 395 F.3d 932 (9th Cir. 2002).

109 See supra Part III.A.

110 Rachel Chambers, The Unocal Settlement: Implications for the Developing Law on Corporate Complicity in Human Rights Abuses, 13 HuM. RTs. BRIEF 14, 14 (2005).

111 Bowoto v. Chevron Corp., No. C 99-02506 SI, 2006 WL 2455761 (N.D. Cal. Aug. 22, 2006) (allowing Nigerian plaintiffs' claim against Chevron for negligence and intentional torts relating to Chevron's response to rebels' taking of an oil platform in Nigeria to proceed to trial, which resulted in a jury verdict for the defendants).

112 See, e.g., Aguinda v. Texaco, Inc., 142 F. Supp. 2d 534 (S.D.N.Y. 2001). 
corporate defendants. Nagiel argued that state statutory and common law causes of action were viable alternatives to the ATS for wrongs committed outside the United States. ${ }^{113}$

With the restrictions placed on the use of the ATS in Kiobel, there was renewed interest among the academy in state common law tort claims as a vehicle for transnational business and human rights litigation. ${ }^{114}$ The predicted increase in conventional tort litigation of business and human rights cases in the wake of the Kiobel decision has not occurred, however. ${ }^{115}$ In fact, there are only isolated

113 Svetlana Meyerzon Nagiel, Note, An Overlooked Gateway to Victim Compensation: How States Can Provide a Forum for Human Rights Claims, 46 Colum. J. TRANSNAT'L L. 133, 165 (2007); see also Drimmer, supra note 107, at 992-95 (recording the conventional tort litigation trend).

114 See generally Paul Hoffman \& Beth Stephens, International Human Rights Cases under State Law and in State Courts, 3 U.C. IRVINE L. REV. 9 (2013) (arguing that, as long as a state court had personal jurisdiction over the defendant, that court would generally have jurisdiction to hear claims arising out of human rights violations in a foreign state and setting out various advantages and disadvantages of litigating in state courts as compared to federal claims litigated in federal courts); Alford, supra note 13 (arguing that the most likely avenue for plaintiffs post Kiobel would be pleading violations of state or foreign tort laws); Nora Mardirossian, Direct Parental Negligence Liability: An Expanding Means to Hold Parent Companies Accountable for the Human Rights Impacts of Their Foreign Subsidiaries 6 (2015), http://ssrn.com/abstract=2607592 [https://perma.cc/372P-DNE3] (“[R]eturning to this conventional tort litigation under state law may be a more viable option for victims seeking redress."); Donald Earl Childress III, The Alien Tort Statute, Federalism, and the Next Wave of Transnational Litigation, 100 GEO. L.J. 709, 744-49 (2012) (analyzing issues of federalism, choice of law, preemption, and due process that the author predicts will arise as part of the post-ATS wave of transnational litigation in state courts); Gwynne L. Skinner, Beyond Kiobel: Providing Access to Judicial Remedies for Violations of International Human Rights Norms by Transnational Corporations in a New (Post-Kiobel) World, 46 Colum. Hum. RTs. L. Rev. 158, 200 (2014) (arguing that the decision in Kiobel likely meant that many cases brought against businesses for their role in human rights abuses abroad would be brought under state law in either state courts or in federal courts under diversity jurisdiction). On various aspects of the broad trend, see Symposium, Human Rights Litigation in State Courts and Under State Law, 3 U.C. IRVINE L. REV. 1 (2013). Introducing a non-U.S. perspective to the post Kiobel debate, Robert McCorquodale charted the foreign direct liability trend outside the United States and argued that this might reignite claims in the United States on non-ATS bases. Robert McCorquodale, Waving Not Drowning: Kiobel Outside the United States, 107 AM. J. INT'L. L 846, 851 (2013).

115 The author surveyed the websites of the key civil society organizations that litigate corporate accountability cases. These organizations are: Earthrights International, the Center for Constitutional Rights and the Center for Justice and Accountability. The author used the Corporate Legal Accountability resources from the Business and Human Rights Resource Center website and legal databases Nexis Uni and HeinOnline. 
examples of new conventional tort law cases, 116 essentially a continuation of the pre Kiobel state of affairs. The difference post Kiobel is that fewer ATS cases are being brought,117 meaning fewer opportunities for parallel conventional tort claims.

As with ATS litigation, the hurdles for plaintiffs in conventional tort claims relate both to the corporate veil and the jurisdictional veil. Looking first at conventional tort claims, a number of early examples from the 1990s prior to the advent of ATS litigation, including the Bhopal litigation introduced above, were dismissed by the courts on forum non conveniens grounds. ${ }^{118}$ Related to the jurisdictional veil, under this doctrine the court dismisses a case on the basis that another forum-usually the host state-is more "convenient" for the litigation. ${ }^{119}$ The corporate veil has featured as a reason for dismissal in more recent conventional tort cases. One example is Gomez v. Dole Food Co., which was dismissed in 2012 because of the plaintiffs' failure to properly plead alter ego and to join Dole's Colombian subsidiary, a necessary and proper party to the litigation. ${ }^{120}$ Another example is Doe I v. Wal-Mart Stores, Inc.,121 which concerns the contractual veil rather than the corporate veil. The plaintiffs presented four distinct legal theories to support their argument that Wal-Mart's Standards for Suppliers and California common law provide substantive obligations that can be enforced by foreign workers in the Wal-Mart supply chain against Wal-Mart, including the negligent breach of duty to monitor suppliers and protect the plaintiffs from the suppliers' working conditions. ${ }^{122}$ In dismissing the case, the court rejected all four theories.

When conventional tort claims are brought alongside ATS claims, with some exceptions, their fate seems to be linked to that of

116 See, e.g., Acuña-Atalaya v. Newmont Mining Corp., 308 F. Supp. 3d 812 (D. Del. 2018), vacated and remanded, 765 F. App'x 811 (3d Cir. 2019); Kashef v. BNP Paribas S.A., 442 F. Supp. 3d 809 (S.D.N.Y. 2020). Kashef is not about attributing liability to the parent company for its role in the wrongdoing of an affiliate company.

117 See supra note 114.

118 Drimmer, supra note 107, at 993 (citing Torres v. S. Peru Copper Corp., 965 F. Supp. 899 (S.D. Tex. 1996); Delgado v. Shell Oil Co., 890 F. Supp. 1324 (S.D. Tex. 1995)).

119 SKINNER, MCCORQUODAlE \& DE SCHUTTER, supra note 38, at 25.

120 No. B228876, 2011 WL 5085007, at *1 (Cal. Ct. App. Oct. 27, 2011).

121572 F.3d 677, 683-84 (9th Cir. 2009). See also Madeleine Conway, A New Duty of Care? Tort Liability from Voluntary Human Rights Due Diligence in Global Supply Chains, 40 QUEEN's L.J. 741, 774-77 (2015).

122 Walmart, 572 F.3d 677. 
the ATS claim. Only a few parallel claims remain intact post Kiobel and Jesner. One such case is Doe I v. Exxon Mobile Corp., discussed above. The ATS claims were dismissed in June 2019 but the conventional tort claims for wrongful death; battery; assault; arbitrary arrest, detention, and false imprisonment; and negligence remain. ${ }^{123}$ These claims are governed by Indonesian law. ${ }^{124}$ Likewise in Doe v. Chiquita Brands Int'l, Inc., claims under the ATS were dismissed, leaving only claims under Colombian law, which were due to be heard in the Southern District Court of Florida in October 2019.125 Nestlé USA, Inc. v. Doe I, also discussed above, is on-going both as an ATS claim and under California state law. ${ }^{126}$ As noted there, the focus of court decisions thus far in this matter is the viability of the ATS claim. ${ }^{127}$ Al-Shimari v. CACI Premier Tech., Inc., is on-going both under the ATS and as a conventional tort law claim, again the current focus of the courts being the viability of the ATS claim. ${ }^{128}$ In summary, there are only a few transnational business and human rights cases - both ATS and conventional tort lawcurrently before the U.S. courts. The difficulty attributing liability to parent corporations is one of the reasons such cases are dismissed.

\section{c. Overcoming the Corporate Veil}

As seen in the preceding sections, the corporate veil is a hurdle to plaintiffs in both ATS and conventional tort litigation. There are two aspects to proving liability of the parent company in ATS litigation: the first is imputing liability to the parent company when the wrongdoer is a subsidiary company, the second is proving the parent company liable as primary violator of customary international law norm, or under secondary liability concepts such as aiding and abetting. ${ }^{129}$ Imputing liability to the parent company,

123 Doe v. Exxon Mobil Corp., 391 F. Supp. 3d 76, 78 (D.D.C. 2019).

124 Id. This means that U.S. law on attributing liability to parent companies will not be applied.

125 No. CV 07-3406 (JMV), 2018 WL 497322 (D.N.J. Jan. 19, 2018).

126141 S. Ct. 188 (2020).

127 Al Shimari v. CACI Premier Tech., Inc., 758 F.3d 516, 528-30 (4th Cir. 2014).

128 Id. This is also the position in Adhikari v. KBR Inc., No. 4:16-CV-2478, 2017 WL 4237923 (S.D. Tex. Sep. 25, 2017) (Adhikari II).

129 Douglas M. Branson, Holding Multinational Corporations Accountable? Achilles' Heels in Alien Tort Claims Act Litigation, 9 SANTA ClaRA J. INT'L L. 227, 241 
the focus here, can be achieved in different ways: piercing the corporate veil; under agency theory; or under enterprise liability theory. ${ }^{130}$ There is no clear precedent on whether state law or federal common law applies to determine derivative liability by which the faults of the subsidiary can be attributed to the parent in ATS litigation, however.131 In Bowoto v. Chevron Texaco Corp., a key precedent in this field, the judge applied federal common law.132 Likewise in the Unocal litigation, discussed above, federal common law was applied to determine the question of attributing liability to the U.S. parent corporation. ${ }^{133}$ In contrast, in Presbyterian Church of Sudan v. Talisman Energy, Inc. ${ }^{134}$ the district court judge applied the conflicts of law regime of the forum, New York, to determine which state's law would apply to the question of piercing the corporate veil. $^{135}$ The situation is more straightforward when conventional tort claims are litigated in state courts, because plaintiffs have only one of these challenges: to impute liability to the parent company. The law that will be applied to determine parent company liability may be that of the state where suit is brought or, depending on the conflicts of law of the forum, foreign law. Assuming U.S. law applies, the parent company can be made liable by piercing the corporate veil under agency theory or under enterprise liability theory.

(2011). The test for accessory liability (aiding and abetting) under the ATS has been approached in different ways by different circuits. The first question is whether the law to apply to determine accessory liability is international law or federal common law. There is now settled case law establishing that international law is applicable. See Srish Khakurel, The Circuit Split on Mens Rea for Aiding and Abetting Liability Under the Alien Tort Statute, 59 B.C.L. REV. 2953, 2966 (2018).

130 The third, enterprise liability, is advocated by certain scholars; for example, Meredith Dearborn argued that enterprise liability should be reconsidered for torts committed by corporate groups. Meredith Dearborn, Enterprise Liability: Reviewing and Revitalizing Liability for Corporate Groups, 97 CAL. L. REV. 195 (2009); see also Virginia Harper Ho, Of Enterprise Principles and Corporate Groups: Does Corporate Law Reach Human Rights? 52 COLUM. J. TRANSNAT'L L. 101 (2013).

131 Simon Baughen, Human Rights and Corporate Wrongs: Closing the GOVERNANCE GAP 155-56 (2015).

132 Id.

133 Id. at 156. Federal common law was also applied in In re South African Apartheid Litigation, 617 F. Supp. 2d 228 (S.D.N.Y. 2009).

134453 F. Supp. 2d 633 (S.D.N.Y. 2006).

135 BAUGHEN, supra note 131, at 156. 


\section{d. Acuña-Atalaya v. Newmont Mining Corp.}

A recent case, Acuña-Atalaya v. Newmont Mining Corp.,136 is emblematic of the approach adopted by plaintiffs to attribute liability to parent companies in transnational business and human rights litigation. This is a rare example in such litigation of plaintiffs suing the American parent corporation in tort law in the federal court, with no parallel ATS claim. It is relevant to this Article because the plaintiffs seek to attribute liability to the parent company for wrongdoing ostensibly at the hands of the subsidiary. ${ }^{137}$ The plaintiffs are subsistence farmers who live in the rural highlands of Cajamarca, Peru. The plot of land where they have cultivated crops and raised livestock for over 20 years, called Tragadero Grande, is claimed by the corporation as part of the site of a planned gold mine. The plaintiffs allege that the corporation has instituted a campaign of harassment against them since 2011 in an attempt to oust them from Tragadero Grande. Specific allegations against the company and its security contractors include intimidation, assault, surveillance, trespass, and unlawful detainment. 138

The plaintiffs have sued the American parent company, Newmont Mining Corp., and three of its American subsidiaries. The Newmont subsidiary operating the mine in Peru, a company called Minera Yanacocha ("M.Y."), is not a defendant in the proceedings. Security at the planned Conga mine site was provided via a contract between M.Y. and Swedish firm Securitas, and via a memorandum of understanding between M.Y. and the Peruvian National Police. ${ }^{139}$ The plaintiffs assert that security operations were carried out with the full approval and knowledge of the Newmont Mining Corp. by showing, for instance, how employees that control the security procedures of M.Y. are current or former employees of the parent

136 No. 17-1315, 2020 WL 1154783 (D. Del. Mar. 10, 2020).

137 In Kashef v. BNP Paribas S.A., 925 F.3d 53, 55 (2d Cir. 2019), the allegations are made directly against the parent company as well as against a subsidiary company.

138 The formal charges are battery, assault, intentional infliction of emotional distress, intrusion on plaintiff's physical solitude, negligence, negligent infliction of emotional distress, negligent hiring, negligent supervision, malicious prosecution, abuse of process, trespass to chattels, and conversion. See Complaint for Damages and Equitable Relief at 79-89, Acuña-Atalaya v. Newmont Mining Corp., 308 F. Supp. 3d 812 (D. Del. 2017) (No. 17-1315).

139 Id. ๆ $183-211$. 
company. ${ }^{140}$ They therefore assert liability against the parent company primarily by attempting to show that M.Y. is its agent, and that the alleged torts were within the course and scope of the agency. ${ }^{141}$ As an alternative line of argument, which is far less developed in the case papers, the plaintiffs make an allegation that resembles "direct liability" used in the common law jurisdiction cases: they allege that the defendants are directly liable for negligent supervision of mine security. ${ }^{142}$

These arguments have not yet been tested in court. As commonly occurs in transnational tort litigation, the defendants challenged the plaintiffs' decision to sue in the United States, arguing that Peru is the appropriate forum for the case to be heard. The most recent decision in the litigation is that of the Third Circuit Court of Appeals, which ruled that the case should be heard in Peru. ${ }^{143}$ The arguments deployed in the Acuña-Atalaya litigation are illustrative of the approach adopted by plaintiffs to attribute liability to parent companies in transnational business and human rights litigation.

\section{i. $\quad$ Veil Piercing / Enterprise Liability}

The plaintiffs in Acuña-Atalaya argue that the Peruvian subsidiary, M.Y., is the corporate defendant's alter ego, or in other words, that the corporate veil should be pierced. ${ }^{144}$ Piercing the corporate veil is very difficult to achieve in practice, essentially requiring an extremely high degree of control over the activities of the subsidiary such that the subsidiary has no separate identity of its own. ${ }^{145}$ In the key precedent on this question, Bowoto v. Chevron

$140 \quad$ Id. ๆ 212-20.

141 Brief in Support of Motion for Preliminary Injunction at 10-11, AcuñaAtalaya v. Newmont Mining Corp., 308 F. Supp. 3d 812 (D. Del. 2017) (No. 17-1315) [hereinafter Acuña-Atalaya Brief in Support of Motion].

142 Id. at 18.

143 Acuna-Atalaya v. Newmont Mining Corp, No. 20-1765 (3d Cir. filed Dec. 11, 2020); see also Kate Fried, U.S. Federal Appeals Court Rules that Maxima Acuña Atalaya's Case Against Newmont Mining Corporation Should be Heard in Peru, EARTHRIGHTS INTERNATIONAL (Dec. 14, 2020), https:/ / earthrights.org/media/u-sfederal-appeals-court-rules-that-maxima-acuna-atalayas-case-against-newmont-m ining-corporation-should-be-heard-in-peru/ [https://perma.cc/BN3G-Y4TJ].

144 Id.

145 See Blumberg, supra note 39, at 304-07; see generally supra Part II (discussing the corporate veil). 
Texaco Corp., the allegation was that Chevron's Nigerian subsidiary, Chevron Nigeria Ltd. (CNL), recruited the Nigerian military and police to fire on protesters on an oil platform, and provided them with transportation from which they launched this and a second attack on a Nigerian village. ${ }^{146}$ The issue before the court was whether the parent company could be liable for the acts of its subsidiary. The judge held that the alter ego theory did not apply on the facts alleged by the plaintiffs, because the plaintiffs could not show that the subsidiary was a mere instrumentality of the parent company. ${ }^{147}$ Reflecting the challenge of piercing the corporate veil, the plaintiffs in Acuña-Atalaya argue alter ego as an alternative to their primary argument, agency, and do not expand on their argument in their brief in support of a preliminary injunction, focusing their efforts for this application on agency only. ${ }^{148}$ Likewise the plaintiffs argue enterprise theory as an alternative means of attributing liability to the parent company, but do not expand on this argument in their motion in support of a preliminary injunction, reflecting how difficult it is to successfully use enterprise theory in practice. ${ }^{149}$

\section{ii. Agency}

As noted above, a parent company may be found liable in a transnational business and human rights claim where its subsidiary is found to have acted as its agent in respect of the particular action giving rise to the claim. ${ }^{150}$ The test for agency does not require the court to disregard the formalities of the corporate veil but instead, through vicarious liability, the principal or employer is held strictly liable for the acts or omissions of its agents that were within the course and scope of the agency. In Bowoto v. Chevron Texaco Corp., the judge, in addition to holding that the alter ego theory did not apply, considered the question of agency. ${ }^{151}$ To support a finding of

146312 F. Supp. 2d 1229, 1233 (N.D. Cal. 2004).

147 Id. at 1246-47.

148 Acuña-Atalaya Brief in Support of Motion, supra note 141, at 10-17.

149 Id.

150 See generally Ma Ji, Multinational Enterprises' Liability for the Acts of Their Offshore Subsidiaries: The Aftermath of Kiobel and Daimler, 23 MicH. ST. INT'L L. REv. 397 (2015) (discussing agency in the transnational business and human rights litigation context).

151312 F. Supp. 2d 1229 (N.D. Cal. 2004). 
agency, the judge found there must be "a close relationship or domination between parent and subsidiary." 152 The act for which liability is sought must be within the scope of the subsidiary's authority as agent. The court in Bowoto found evidence to support a finding that the subsidiary, CNL, was Chevron's agent, including communications suggesting a close relationship regarding security, the parent setting security policies, the parent and subsidiary sharing officers and directors, the subsidiary's importance to the parent; and the parent holding the subsidiary out to be a department of its own business. ${ }^{153}$ These last factors can be summarized in the question: had the subsidiary engaged in activities which, but for the subsidiary, the parent would have had to undertake itself? On the basis of these facts, the court allowed the plaintiffs' claim against Chevron for negligence and intentional torts to proceed to trial, which resulted in a jury verdict for the defendants. ${ }^{154}$ In Doe I $v$. Exxon Mobil Corp., it was similarly held that a jury could conclude that a subsidiary was the agent of its parent with regard to security for the subsidiary's project, where the parent "exerted significant control over [the subsidiary's] security, particularly through [the parent's] Global Security Division." 155

The plaintiffs in Acuña-Atalaya argue that M.Y. is Newmont Mining Corp.'s agent "at least for security purposes, including dealing with the [p]laintiffs." 156 They support this argument with evidence showing an overlap of personnel between the companies; the parent company setting standards and policies for M.Y., including on human rights and security; and parent company control of security via a group-wide security program and reporting structures. ${ }^{157}$ The defendant in Acuña-Atalaya argues that the relationship between parent and subsidiary is sufficient to establish agency only where the parent company dominates the activities of

152 Id. at 1239.

153 Id. at 1243.

154 Id. at 1250; Bowoto v. Chevron, EarthRights International, https:/ / earthrights.org/case/ bowoto-v-chevron-2/\#documentsff69-1a905f26f4b6 [https://perma.cc/6JAL-G46Q].

155573 F. Supp. 2d 16, 31-32 (D.D.C. 2008). The court allowed the Indonesian plaintiffs' claims of wrongful death, theft by coercion, and assault and battery against Exxon relating to natural gas extraction activities in Indonesia to proceed to trial.

156 Acuña-Atalaya Brief in Support of Motion, supra note 141, at 16.

157 Id. at 16-17. 
the subsidiary that relate to the claim. ${ }^{158}$ They deny that the plaintiffs have met the burden to establish such a relationship. ${ }^{159}$

\section{iii. $\quad$ Direct Parent Liability}

Direct parental negligence liability for harm caused by a subsidiary has yet to be established in U.S. case law. ${ }^{160}$ At least one leading scholar contends that the United States courts may at some point accept the direct liability argument in transnational tort litigation, implicitly clarifying that there is no reason in principle for courts not to do so. ${ }^{161}$ There has however been one occasion on which the Supreme Court laid out an opportunity for parents to be directly liable under the terms of a specific statute: the Comprehensive Environmental Response, Compensation and Liability Act, known as CERCLA. ${ }^{162}$ This was a domestic case. Proceedings were brought under the Act against CP International Inc. in respect of the activities of its then defunct subsidiary, Ott Chemical Co. ${ }^{163}$ The suit was for the costs of cleaning up industrial waste generated by the Ott Chemical Co. plant. 164 The Act allowed suit to be brought against "any person who at the time of disposal of any hazardous substance owned or operated any facility at which hazardous substances were disposed of . ..."165 The question for the Court was whether the paper company operated the Ott Chemical Co. plant for the purpose of the Act. ${ }^{166}$

158 Answering Brief of Defendants in Opposition to Plaintiffs' Motion for a Preliminary Injunction at 16, Acuña-Atalaya v. Newmont Mining Corp., 308 F. Supp. 3d 812 (D. Del. 2017) (No. 17-1315).

159 Id. at 17.

160 Mardirossian, supra note 114 , at 5.

161 Vivian Grosswald Curran argues, "[w]hen they consider arguments rebutting the presumption against extraterritoriality, in expanding agency theory with respect to foreign subsidiaries, and in creating a direct duty of care theory, U.S. judges may also be more likely to take greater note of Canadian decisions such as HudBay and Vedanta...." Curran, supra note 57, at 443.

162 See United States v. Bestfoods, 524 U.S. 51, 64-73 (1998) (discussing parent liability under CERCLA).

163 Id. at 51.

164 Id. at 55 .

165 Comprehensive Environmental Response, Compensation, and Liability Act, 42 U.S.C. § 9607(a)(2) (2018).

166 Bestfoods, 524 U.S. at 60. 
The Supreme Court held that a parent corporation could not be found liable under CERCLA for a subsidiary's environmental practices merely on account of its active involvement in the subsidiary's general affairs. ${ }^{167}$ But the parent could be found directly liable as an "operator" based on its management, direction, or conduct specifically related to pollution at the facility for instance when joint officers conducted the affairs of the subsidiary on behalf of the parent. ${ }^{168}$ Based on this finding, the Court remanded the case to the lower courts for re-evaluation and resolution. ${ }^{169}$ It is noteworthy that the Supreme Court's approach was to focus on positive involvement by the parent company in the harmful activity of the subsidiary that goes beyond established norms of corporate behavior. ${ }^{170}$ Thus, as will be demonstrated below, it differs considerably from the approach to direct liability in English law.

Ashton Philips argues that there has been one instance of direct parent company liability in tort litigation, a case from Illinois in which a parent company was held to be directly liable to the employees of its subsidiary when budgetary restrictions imposed by the parent left the subsidiary exposed to health and safety risks, which materialized in the form of a factory fire.171 The Supreme Court of Illinois held that "it is 'axiomatic that every person owes to all others a duty to exercise ordinary care to guard against injury which naturally flows as a reasonably probable and foreseeable consequence of his act.'"'172 Therefore, the parent company could be liable as a "direct participant" for any injuries caused by its affirmative mismanagement. ${ }^{173}$ A subsequent decision of the Superior Court of Massachusetts disapproved of this decision, however, doubting whether the Illinois court had correctly applied

167 Id. at 60-64.

168 Id. at 66-67.

169 Id. at 73.

170 BAUGHEN, supra note 131, at 162.

171 Ashton S. Phillips, Transnational Businesses, the Right to Safe Working Conditions, and the Rana Plaza Building Collapse: Toward a Tort-Based Solution to the Global Race to the Bottom, in THE Business AND HumAn Rights LANDSCAPE: Moving FORWARD, LOOKING BACK 468, 484-485 (Jena Martin \& Karen E. Bravo eds., 2016) (citing Forsythe v. Clark USA, Inc., 224 Ill. 2d 274, 278, 864 N.E.2d 227, 231 (2007)).

172 Forsythe v. Clark USA, Inc., 864 N.E.2d 227, 238 (Ill. 2007) (citing Frye v. Medicare-Glaser Corp., 605 N.E. 2d 557 (1992)).

173 Id. at 235. 
Bestfoods in adopting its theory of direct participant liability. ${ }^{174}$ As Phillips acknowledges, the Ninth Circuit also reached a conflicting result in the case of Doe I v. Wal-Mart Stores, Inc., 175 discussed above. As noted there, this case differs from the cases discussed so far in that it concerns attributing liability to a lead company for harm to the plaintiffs caused by a supplier, not by a subsidiary. The legal principles that apply are arguably similar, however. ${ }^{176}$ The plaintiffs alleged common law negligence, relating to Wal-Mart's inadequate monitoring of its subcontractors' factories. The Ninth Circuit affirmed the District Court's dismissal of the negligence claims on the ground that Wal-Mart "did not owe [p]laintiffs a common-law duty to monitor Wal-Mart's suppliers or to prevent the alleged intentional mistreatment of plaintiffs by the suppliers." 177

Direct liability is used to make a narrow argument in AcuñaAtalaya. The plaintiffs claim that liability attaches where the defendant is negligent in supervising an activity or in permitting, or failing to prevent, tortious conduct by persons "upon premises or with instrumentalities under the defendant's control."178 In essence, they say that the defendants oversaw and controlled security and knew about the ongoing intimidation at the proposed mine site yet failed to ensure that security personnel stopped harassing plaintiffs. The authority cited is Doev. Exxon Mobil Corp., in which the plaintiffs alleged that the subsidiary was directly liable for the negligent supervision of Indonesian security personnel, and that the parent company was liable for the acts of the subsidiary under various theories, including agency.179 The court in Exxon decided that a

174 Born v. Simonds Int'l, Corp., 200602483C, WL 5905396, at *5 (Mass. Super. Ct. Dec. 30, 2009). Courts in Illinois are following the Forsythe decision, however. See, e.g., Deatherage v. D Transp., Inc., 4 N.E.3d 1108 (Ill. 2013).

175572 F.3d 677 (9th Cir. 2009); see also Phillips, supra note 171, at 485.

176 See SHELdON LEADER, JANE Wright \& ANIL YiLMAZ, LEgAl Opinion ON ENGLISH COMMON LAW PRINCIPLES OF TORT: JABIR AND OTHERS V KIK TEXTILIEN UND NON-FOOD GMBH (2015) [hereinafter LEGAL OPINION ON JABIR].

177 Wal-Mart Stores, Inc., 572 F.3d at 683.

178 Acuña-Atalaya Brief in Support of Motion, supra note 141, at 18 (citing Doe v. Exxon Mobil Corp., 573 F. Supp. 2d 16, 29-30 (D.D.C. 2008)).

179

An employer conducting activity through servants or other agents is liable for negligent supervision if the employer is negligent or reckless (1) in giving improper or ambiguous orders or in failing to make proper regulations; (2) in the employment of improper persons or instrumentalities in work involving risk of harm to others; (3) in the supervision of the activity; or (4) in permitting, or failing to prevent, 
reasonable trier of fact could conclude that the subsidiary was liable for negligent supervision, in addition to accepting the plaintiffs' prima facie case on agency. It therefore denied summary judgment on this allegation. 180 The difference between Exxon and AcuñaAtalaya is that the allegation of direct liability is against the parent company in Acuña-Atalaya, which is one step removed from the subsidiary that engaged the services of the security personnel. Thus, this argument is potentially more difficult to sustain. More broadly, this type of direct liability relates only to negligent supervision and requires a higher level of oversight and control over the relevant activity than the direct liability argument used in the English cases, discussed in the next Part.

\section{ENGLISH CASES: ON THE RISE}

This Part tracks the rise of transnational business and human rights litigation in England. The case analysis demonstrates that the path of this litigation has not been smooth, with courts taking one step forward, and two steps back. It is against this background that the U.K. Supreme Court's decisions in Lungowe and Okpabi provide an important marker of the approach of the courts going forward, giving sanction at the highest level for the direct parent company liability to be understood through a wider lens than it has been in certain instances in the past.

\section{a. Background to the Tort Claims}

Since the late 1990s, a number of transnational business and human rights cases have been brought in the English High Court. With no statutory equivalent to the ATS, these cases have been based on the tort of negligence. They seek to impose direct liability for

negligent or other tortious conduct by persons, whether or not servants or agents, upon premises or with instrumentalities under the person's control.

Exxon Mobile Corp., 573 F. Supp. 2d at 29 (citation omitted).

180 Id. at 30 
actions or omissions by the parent company in respect of harm committed abroad. 181

An English case with a similar fact pattern to Acuña-Atalaya, but in which direct liability was argued against the parent company, had a swift and positive outcome for the plaintiffs, in contrast to the outcome in Acuña-Atalaya. This case, Guerrero v. Monterrico Metals PLC, was brought against a U.K.-parent company, Monterrico Metals, and its wholly owned Peruvian subsidiary, Rio Blanco Copper SA, concerning protests that took place in Peru about the company's proposal to develop a copper mine there. ${ }^{182}$ The plaintiffs were 31 protesters and their family members who were hooded, bound, and detained over a period of days by members of the Peruvian National Police. ${ }^{183}$ Two women alleged that they were sexually assaulted. 184 One protester died. ${ }^{185}$ The plaintiffs' claims were for false imprisonment, trespass to the person (torture) and negligence. They sought damages for the injuries inflicted upon them by Peruvian police officers, 186 instigated and aided by the mine management. ${ }^{187}$ The plaintiffs' contention was that officers of the company "ought to have intervened so as to have prevented the abuse of the [c]laimants' human rights." 188 The parent company was said to have exercised "effective control over the management of

181 In one of the early cases, for example, Connelly v. RTZ Corp. PLC [1997] UKHL 30 (HL) (Eng.), a worker suffering from laryngeal cancer who had been employed at RTZ's uranium mine in Namibia brought such a claim. Id. I 1. He alleged that the England-based RTZ parent company took key strategic technical and policy decisions relating to the mine. Id. 9 3. In particular, he alleged that RTZ had devised the mine's policy on health, safety and the environment and/or had advised the mine as to the contents of the policy. Id. Thus, the foundation of the plaintiff's claim was that the parent company owed him a direct duty of care, independent of the duty of care owed to him by his employer. This argument was met with approval by the courts. Id. at 33. The House of Lords accepted that there was an arguable case against the parent company, in a forum non conveniens judgment in the plaintiffs' favor. $I d$. ๆ 4 . The action failed, however, because it had been initiated outside the limitation period allowed by law. Id. at 21, 33.

182 See generally Guerrero v. Monterrico Metals PLC [2009] EWHC 2475 (QB) (Eng.) (removing Rio Blanco SA as a defendant when it became clear to the plaintiffs' lawyers that the absence of a treaty between Peru and the United Kingdom would make it difficult to enforce any English judicial decision.). See Meeran, supra note 29.

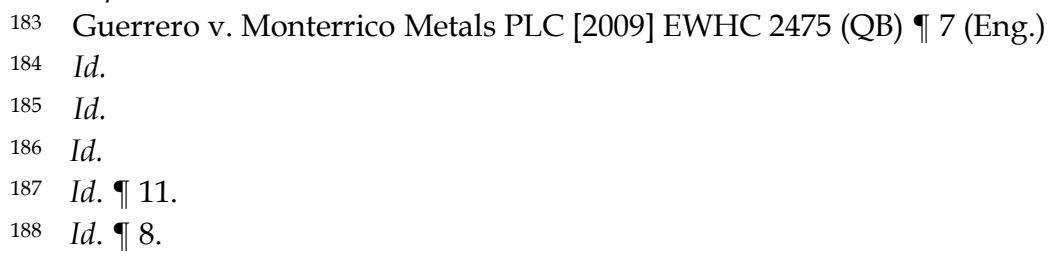


the" subsidiary and was therefore directly liable to the plaintiffs. ${ }^{189}$ The litigation came before a judge in the context of an application for a freezing order to ensure that the company retained sufficient assets in the U.K. to meet its potential liabilities in the case. ${ }^{190}$ The application required the judge to consider whether the plaintiffs had made out a good arguable case against the parent company, on the basis of the parent company's involvement described above. The plaintiffs were successful,191 and the parties reached a financial settlement that concluded the litigation, shortly after this application was decided in the plaintiffs' favor. ${ }^{192}$

The decision in Chandler v. Cape PLC ${ }^{193}$ was an important legal milestone in the direct liability line of cases, albeit in a domestic case concerning U.K.-based parent and subsidiary companies. This is the only English direct liability case to have been won by the plaintiffs following a full trial of the facts - all the other direct liability cases have been lost or settled after court decisions on jurisdiction. ${ }^{194}$ The trial judgment was subject to an appeal, and the Court of Appeal affirmed the lower court's decision that, in appropriate circumstances, the law may impose a duty of care on a parent company in respect of its subsidiary's employees. ${ }^{195}$ The court set out four indicia of the appropriate circumstances that establish the parent's knowledge of the potential harm to the plaintiff and the subsidiary's or its employees' reliance on that knowledge for the employees' protection, which together formed the basis of the parent's duty of care. ${ }^{196}$ On the facts of the case, the court found that the parent had assumed responsibility towards the plaintiff in circumstances where the parent company had installed its asbestos production business at its subsidiary's site and maintained a certain level of control over the business, through involvement in and influence over its subsidiary's operations. ${ }^{197}$ This control was illustrated by the parent issuing instructions about company products; the parent placing requirements on the subsidiary that it

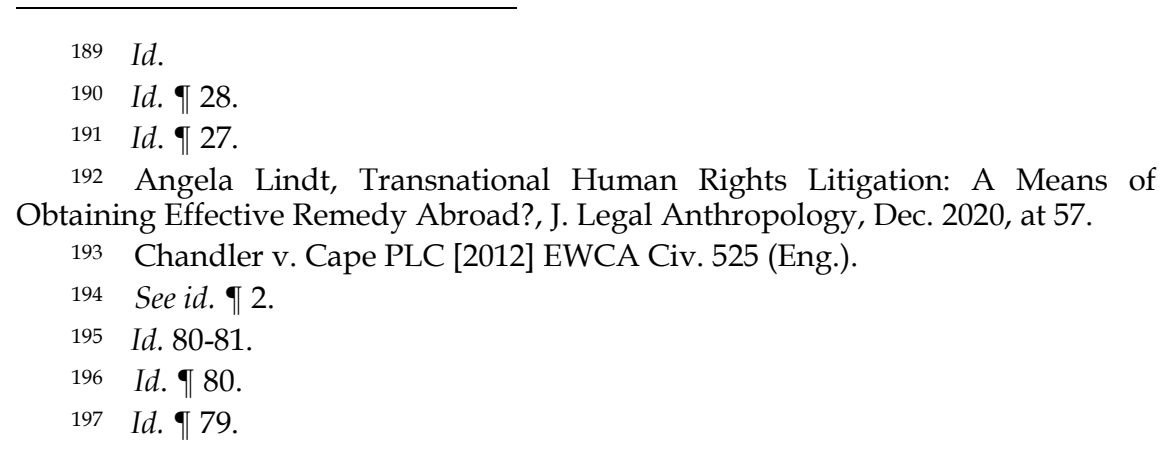


seek approval before incurring capital expenditures; the parent's centralized product development process; and its common company policies. ${ }^{198}$ The finding of a direct duty of care on the parent company has been relied on as precedent in a series of subsequent cases, discussed next.

\section{b. The Current Wave of Litigation}

There has been a steadily growing trickle of tort cases against transnational corporations in the English courts, boosted by Chandler and also by legal developments at the European level. In 2005, a decision of the European Court of Justice clarified that under the relevant European law, ${ }^{199}$ national courts of European states do not have the power to dismiss cases brought against European defendants on the grounds that a court of a non-European state would be a more appropriate forum for the trial of the action (i.e., on forum non conveniens grounds). ${ }^{200}$ Following this judgment, a handful of transnational business and human rights cases were brought in which, unable to avail themselves of the defense of forum non conveniens, corporate defendants did not challenge jurisdiction of the English courts, at least not over the English parent company.201 In these cases, both the English parent company and the foreign subsidiary were sued. The joining of the foreign company as co-defendant in connected claims was also made possible under the relevant European law. ${ }^{202}$

198 Martin Petrin, Assumption of Responsibility in Corporate Groups: Chandler v Cape PLC, 76 Modern L. Rev. 603, 612 (2013). The judgment in a subsequent case, Thompson v. Renwick Group [2014] EWCA Civ. 635 (Eng.), confirmed that a plaintiff would have had to show that the parent company was better placed, through superior knowledge or expertise, to protect its subsidiary's employees against the risk of injury that materialized. In contrast, the parent company merely holding shares in the subsidiary did not satisfy the test.

199 Brussels Regulation, supra note 51.

200 Owusu v. Jackson [2005] ECR 1383 (Eng.). This position is now changed since the United Kingdom's exit from the European Union. See Ekaterina Aristova, The Future of Tort Litigation against Transnational Corporations in the English Courts: Is For [Non] Conveniens Back?, Bus. HuM. RTs. J., May 21, 2021, at 1.

201 See, e.g., Guerrero v. Monterrico Metals PLC [2009] EWHC 2475 (QB) (Eng.); Bodo Cmty. v. Shell Petroleum Dev. Co. of Nigeria [2014] EWHC 958 (TCC) (Eng.); Kesabo v. African Barrick Gold PLC [2013] EWHC 3198 (QB) (Eng.).

202 Brussels Regulation, supra note 51, art. 8. Member states' domestic laws apply when the defendant corporation in the connected claim is domiciled outside the European Union. 
Then came a shift in tactics. Corporate defendants began to challenge jurisdiction by arguing, inter alia, that the plaintiffs in these cases did not have an arguable case against the domestically domiciled corporate defendant (usually the parent company) also known as the "anchor defendant" (because this defendant anchors the claim in the jurisdiction). The test for jurisdiction over the parent company is premised on there being "between the claimant and the defendant a real issue which it is reasonable for the court to try." 203 A "real issue to be tried" equates to an arguable case. The arguable case that the plaintiffs have sought to establish is of direct liability of the domestic defendant. A trilogy of recent cases illustrates the different approaches the courts have taken when they identify features relevant to deciding whether a parent company owes a duty of care to the plaintiffs, and thus whether there is an arguable case against the domestic defendant. ${ }^{204}$ These cases represent the cutting edge of the law on direct parent liability. Although the applicable law in each of these cases is the law of the jurisdiction where the harm occurred (Zambia, Nigeria, and Kenya respectively), the relevant countries are common law jurisdictions, which draw on foreign law as precedent, including English law, in novel cases such as these. When viewed as a trilogy, the importance of Lungowe, the case discussed first, becomes apparent.

\section{i. $\quad$ Lungowe v. Vedanta Resources PLC}

This case concerns the impact of pollution from a copper mine in Zambia that is operated by Konkola Copper Mines ("KCM"), the Zambian subsidiary of U.K.-parent company Vedanta Resources. The plaintiffs, 1,826 Zambian citizens, allege that they have suffered personal injury, damage to property, loss of income, and loss of amenity and enjoyment of land arising out of the operation of the

203 U.K. Ministry of Justice, Practice Direction 6B - Service Out of Jurisdiction $\S 3.1(3)(a)$. If there is a "real issue . . f for the court to try" the plaintiffs must still overcome the forum non conveniens hurdle in relation to the foreign subsidiary, but the fact that there is a properly pleaded case against the parent company domiciled in the jurisdiction is indicative that England is the appropriate forum. Id., Vedanta Resources PLC v. Lungowe [2019] UKSC 20, I 13 (Eng.). The precedent on forum non conveniens is beyond the scope of this Article.

204 See Vedanta Resources PLC v. Lungowe [2019] UKSC 20, ף 13 (Eng.); Okpabi v. Royal Dutch Shell PLC [2021] UKSC 3 (Eng.); AAA v. Unilever PLC [2018] EWCA (Civ) 1532 (Eng.). 
mine.205 They make a direct claim of negligence against Vedanta, alleging that it breached the duty of care it owed them to ensure that KCM's mining operations did not cause harm to the environment or local communities. ${ }^{206}$ They also claim against KCM. ${ }^{207}$

To establish Vedanta's direct liability, the plaintiffs had to demonstrate that they had an arguable case that Vedanta owed a duty of care to affected local communities in the area of the mine, and that they breached this duty through their actions and/or omissions. Such a duty of care has only been established once at trial, in Chandler, discussed above. The judge's conclusion that the plaintiffs in Lungowe had established an arguable case of Vedanta's direct liability was premised on four pieces of evidence: Vedanta's sustainability report; the management agreement between Vedanta and KCM; a decision of an Irish court about the structure of the Vedanta corporate group; and the witness statement of a former KCM employee (a whistle-blower). ${ }^{208}$ These pointed towards there being a duty of care between the parent company and the plaintiffs. 209

After the company appealed unsuccessfully to the Court of Appeal, 210 the case reached the U.K. Supreme Court in January 2019.211 The company sought to persuade the court that finding a duty of care on the part of the parent company would involve a novel extension of common law tort, beyond the boundaries of any established category. ${ }^{212}$ The court disagreed. Giving judgment, Lord Briggs held that the critical question determining whether there was an arguable case against Vedanta, was "whether Vedanta sufficiently intervened in the management of the Mine owned by its

\footnotetext{
(Eng.).

205 See Lungowe v. Vedanta Resources PLC [2016] EWHC 975, q 1 (TCC)

206 Id. ๆ 3.

207 Id.

208 Id. I 119.

209 See Caparo Indus. PLC v. Dickman [1990] 2 AC 605 (HL) (Eng.) (applying the test for determining new tortious duties of care). "Proximity" is one of the tests from Caparo Industries for determining new tortious duties of care. The Supreme Court disapproved of this approach on appeal, however, finding that it was not a new tortious duty of care that the plaintiffs sought to establish. See Vedanta Resources PLC v. Lungowe [2019] UKSC 20, ๆ 60 (Eng.).

210 Lungowe v. Vedanta Resources PLC [2017] EWCA Civ. 1528 (Eng.). See also Ekaterina Aristova, Tort Litigation against Transnational Corporations in the English Courts: The Challenge of Jurisdiction, UTRECHT L. REV., June 2018, at 6 (tracing the life of the case).

211 Vedanta Resources PLC v. Lungowe [2019] UKSC 20 (Eng.).

212 Id. \ 46.
} 
subsidiary KCM to have incurred, itself (rather than by vicarious liability), a common law duty of care to the [plaintiffs]."213 There was "nothing special or conclusive about the bare parent/ subsidiary relationship" 214 - "the general principles which determine whether A owes a duty of care to $C$ in respect of the actions of $B$ are not novel at all." 215

The court made it clear that the four indicia from Chandler must not be used formulaically to determine if there is a duty of care. ${ }^{216}$ Taking a more pragmatic approach to the arrangements of multinational corporate groups, it noted that " $\mathrm{t}$ ] here is no limit to the models of management and control which may be put in place within a multinational group of companies." 217 "Everything depends on the extent to which, and the way in which, the parent availed itself of the opportunity to take over, intervene in, control, supervise or advise the management of the relevant operations ... of the subsidiary." 218 This is important because one of the other cases in the trilogy ( $A A A v$. Unilever) failed on the basis that the plaintiffs could not convincingly make a case on the facts that the parent company exercised sufficient control and that the foreign subsidiary relied on that control.219 The careful use of the terminology of "intervention" rather than "control" in Lungowe is striking. 220

Lord Briggs did not conduct the factual analysis of whether sufficient intervention had taken place, which had already been done by the lower court. He noted however that had he done so, the parent company's published materials, such as its sustainability report asserting its responsibility for laying down and implementing standards of environmental control at the mine, were "sufficient on their own to show that it is well arguable that a sufficient level of intervention by Vedanta in the conduct of operations at the Mine may be demonstrable at trial." 221 The

\footnotetext{
213 Vedanta Resources PLC v. Lungowe [2019] UKSC 20, ๆ 44 (Eng.).

$214 \quad I d .954$.

215 Id.

216 Id. 9 | 59-60.

217 Id. T 51. The approach adopted in Okpabi and AAA, discussed below, of categorizing the kind of case in which the parent might incur a duty of care to third parties harmed by the activities of the subsidiary was not adopted in Lungowe. Id. 
defendants had sought to argue a general principle that a parent could never incur a duty of care in respect of the activities of a particular subsidiary merely by laying down group-wide policies and guidelines and expecting the management of each subsidiary to comply with them. The court rejected this argument:

[T] he parent may incur the relevant responsibility to third parties if, in published materials, it holds itself out as exercising that degree of supervision and control of its subsidiaries, even if it does not in fact do so. In such circumstances its very omission may constitute the abdication of a responsibility which it has publicly undertaken. ${ }^{222}$

This represents an extension of Chandler to the situation where a company makes representations about supervision of its subsidiary but omits to act on them. ${ }^{223}$ It also attributes a new legal significance to the content of group-wide policies and reports. Almost two years after the Supreme Court judgment, the litigation ended with a settlement agreement being reached between the parties. 224

\section{ii. Okpabi v. Royal Dutch Shell PLC}

Okpabi and its companion case are parallel claims brought on behalf of the inhabitants of two communities: the Ogale Community and the Bille Kingdom in Ogoniland, Nigeria, which consists of around 40,000 people.225 Over several years there have been repeated oil spills from Shell's pipelines in Ogoniland, many of which have not been cleaned up. ${ }^{226}$ The plaintiffs seek compensation through their suit for "damages arising as a result of serious and ongoing pollution and environmental damage caused

\footnotetext{
$222 \quad$ Id. 953.

223 See Robert McCorquodale, Vedanta v. Lungowe Symposium: Duty of Care of Parent Companies, OPINIO JURIS (Apr. 18, 2019), http:/ / opiniojuris.org/2019/04/18/symposium-duty-of-care-of-parent-companie s/ [https://perma.cc/LXF2-6DQG].

224 Legal Claim by More than 2,500 Zambian Villagers in a Case Against Vedanta Resources Limited, LEIGH DAY (Jan. 19, 2021) https://www.leighday.co.uk/latestupdates/news/2021-news/legal-claim-by-more-than-2-500-zambian-villagers-ina-case-against-vedanta-resources-limited/ [https://perma.cc/7C36-VHW6].

225 Okpabi v. Royal Dutch Shell PLC [2017] EWHC (TCC) 89, ๆ 2-4 (Eng.).

$226 \quad I d .92$
} 
by oil spills emanating from the Defendants' oil pipelines and associated infrastructure." 227 The losses suffered include damage to land, and injury to livelihood and health.228 The case against the U.K.-registered Royal Dutch Shell PLC ("RDS") is based on the common law of negligence and asserts that RDS breached its duty of care to ensure that its subsidiary Shell Petroleum Development Company of Nigeria ("SPDC")'s operations in the Niger Delta did not cause harm to the environment and their communities. ${ }^{229}$ Negligent management is alleged both in relation to maintenance of the pipeline and facilities to acceptable standards, and to taking effective measures to protect them from interference by third parties. ${ }^{230}$ This interference took the form of unlawful siphoning of oil by third parties incurring damage to the pipeline and other facilities, and consequential oil spills. ${ }^{231}$ Shell challenged the jurisdiction of the English courts to hear the case, and the matter came for a preliminary hearing before the High Court. ${ }^{232}$ The judge presiding ruled that the case could not proceed. ${ }^{233}$ As with Lungowe, the plaintiffs needed an arguable case against the U.K.-registered parent company, in order to be able to bring proceedings against both it and its subsidiary, SPDC, in the English courts. This is because RDS is the so-called "anchor defendant" (the defendant domiciled in the jurisdiction).

The High Court's decision that there was not an arguable case was taken against the background to this litigation of RDS having distanced itself from the operational side of oil production. This occurred through a restructure in 2005, which made RDS "the ultimate holding company of the Shell group of companies." 234 The High Court judgment was upheld on appeal in a split decision of the Court of Appeal. ${ }^{235}$ The majority held that the plaintiffs had not established an arguable case that RDS had a duty of care to the Nigerian communities affected by the pipeline. ${ }^{236}$ The available evidence, which at that preliminary stage of the proceedings prior

\footnotetext{
227 Id. (citing the particulars of the claim).

228 Id. 916.

229 Id. 9 3. There are related claims made against the subsidiary, SPDC. Id.

230 Id. 998.

231 Okpabi v. Royal Dutch Shell PLC [2018] EWCA (Civ) 191, ๆ 137 (Eng.).

232 Okpabi v. Royal Dutch Shell PLC [2017] EWHC (TCC) 89, ๆ 6 (Eng.).

233 Id. 122.

$234 \quad$ Id. $ๆ 83$.

235 Okpabi v. Royal Dutch Shell PLC [2018] EWCA (Civ) 191, ๆ 137 (Eng.).

$236 \quad$ Id. $\ 132$.
} 
to discovery was mostly limited to publicly available information including group-wide policies, ${ }^{237}$ did not demonstrate the required control over SPDC. 238

The plaintiffs appealed to the Supreme Court. Overruling the Court of Appeal in a unanimous judgment, the Supreme Court strongly affirmed its decision in Lungowe.239 According to the Supreme Court judgment, the Court of Appeal majority's focus on the parent's control over the subsidiary, SPDC, was inappropriate. Citing Lungowe, the court held:

The issue is the extent to which the parent did take over or share with the subsidiary the management of the relevant activity (here the pipeline operation). That may or may not be demonstrated by the parent controlling the subsidiary. In a sense, all parents control their subsidiaries. That control gives the parent the opportunity to get involved in management. But control of a company and de facto management of part of its activities are two different things. A subsidiary may maintain de jure control of its activities, but nonetheless delegate de facto management of part of them to emissaries of its parent. 240

The Court noted that the internal documents that the plaintiffs would need to demonstrate the role of RDS in managing the SPDC pipeline operation at trial had not been discoverable at this point in proceedings. 241 Two documents that had been acquired by the plaintiffs from a third party, the RDS Control Framework and the RDS Health, Security, Safety and Environment Control Framework, contained important information about operational organization within the Shell group of companies. The Court was concerned that:

The production of [these two documents] for the appeal hearing illustrate the danger of seeking summarily to determine issues

237 Okpabi v. Royal Dutch Shell PLC [2021] UKSC 3, ๆ 136 (Eng.).

238 Okpabi v. Royal Dutch Shell PLC [20180 EWCA (Civ) 191, \ 122 (Eng.).

239 Okpabi v. Royal Dutch Shell PLC [2021] UKSC 3 (Eng.); see also Ekaterina Aristova \& Carlos Lopez, UK Okpabi et al v Shell: UK Supreme Court Reaffirms Parent Companies May Owe a Duty of Care Towards Communities Impacted by their Subsidiaries in Third Countries, OPINIO JURIS (Feb. 16, 2021), http://opiniojuris.org/2021/02/16/uk-okpabi-et-al-v-shell-uk-supreme-court-rea ffirms-parent-companies-may-owe-a-duty-of-care-towards-communities-impacte d-by-their-subsidiaries-in-third-countries/ [https://perma.cc/8HGN-3HNU].

240 Okpabi v. Royal Dutch Shell PLC [2021] UKSC 3, ๆ 147 (Eng.).

241 Okpabi v. Royal Dutch Shell PLC [2021] UKSC 3, ๆ 136 (Eng.). 
which arise in parent/subsidiary cases such as this without disclosure. Both are clearly material documents. Had there been no appeal, the appellants' claim would have been dismissed without consideration of either of them. ${ }^{242}$

The Court's emphasis on the need to consider the full body of evidence on the parent's involvement in the harmful activities, rather than dismissing cases summarily, is welcomed.

\section{iii. AAA v. Unilever PLC}

The facts of the $A A A$ case are quite different to those of the other two cases in the trilogy, and not typical for transnational business and human rights claims. After the Kenyan presidential election in 2007, there was a wave of violence throughout the country. ${ }^{243}$ Riots spread onto a tea plantation owned by one of Unilever's subsidiaries, Unilever Tea Kenya Ltd. (“UTKL").244 The rioters committed a number of atrocities there including rape and murder. ${ }^{245}$ The plaintiffs are tea plantation workers who fell victim to these violent acts, and family members of workers who were killed during the incident. ${ }^{246}$ They sued Unilever and UTKL in England, where Unilever is registered, alleging that the former, as anchor defendant owed them a duty of care and breached that duty by failing to put in place adequate crisis management policies. ${ }^{247} \mathrm{On}$ the question whether Unilever owed a duty of care to the plaintiffs, the trial judge in the High Court found that the damage that occurred on the tea plantation was not foreseeable by either Unilever or UTKL. ${ }^{248}$ Foreseeability is one element of the test for a duty of care in a novel situation. ${ }^{249}$ Another element, proximity, was found to be present and Unilever's corporate structure was distinguishable from that of Shell.250

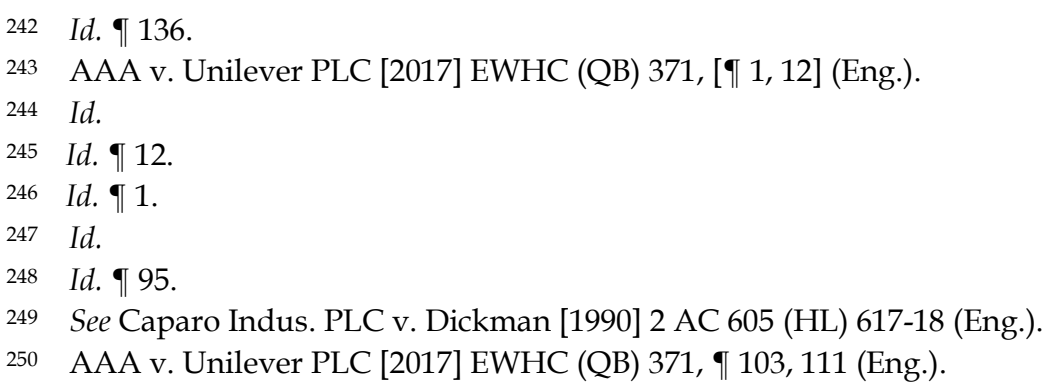


The Court of Appeal upheld the first instance decision on foreseeability but overturned the decision on proximity, finding that there was no proximity between the plaintiffs and Unilever. ${ }^{251}$ Lord Justice Sales wrote the only judgment for the court. He identified two categories of cases where a parent company would owe a duty of care: "(i) where the parent [company] has in substance taken over the management of the relevant activity of the subsidiary in place of ... the subsidiary's own management; or (ii) where the parent [company] has given relevant advice to the subsidiary about how it should manage a particular risk." 252 The latter was potentially applicable. He examined the policies that the company had in place in respect of risk management and found that those provided by the parent company were high-level, generic documents which left the specifics to be established at the local level by the subsidiaries. ${ }^{253}$ Riots like those that occurred in 2007 had not happened on the tea plantation before. Unilever did not hold superior knowledge on local political or ethnic matters. ${ }^{254}$ For these reasons there was no proximity between the parties and the appeal was rejected. The plaintiffs sought permission to appeal the decision to the Supreme Court, but permission was not granted, because the appeal did not meet the test of raising an arguable point of law of general public importance that ought to be considered by the Supreme Court. ${ }^{255}$

\section{c. Discussion of the Trilogy}

Determination of whether a parent company has sufficiently intervened in the operations of its subsidiary to have incurred a common law duty of care to the plaintiffs is a question both of law and of fact. The Supreme Court in Lungowe approached the relevant legal and factual analysis less restrictively for plaintiffs than the Court of Appeal did in both Okpabi and Unilever, in which the formalities of the corporate structure prevailed. When it

\footnotetext{
251 AAA v. Unilever PLC [2018] EWCA (Civ) 1532 (Eng.).

252 Id. ๆ 37.

253 Id. ๆ $17,40$.

254 Id. $\ 14$.

255 See Chris Owen \& Adam Bristow, Supreme Court Refuses Permission to Appeal in Unilever Case, Simmons \& Simmons (Jul. 19, 2019), https://www.simmons-simmons.com/publications/ck0bagorz7ep70b94qy2xfp8 u/190719-mass-torts-case-alert-supreme-court-refuses-permission-to-appeal-in-un ilever-case [https://perma.cc/5VTP-BHM6].
} 
acknowledged the various ways in which parent companies exert management, supervision and control over subsidiaries and held that "[e]verything depends on the extent to which, and the way in which, the parent availed itself of the opportunity to take over, intervene in, control, supervise or advise the management of the relevant operations of the subsidiary," the Supreme Court in Lungowe was acknowledging that there are various levels of intervention that might suffice for the parent company to incur a duty of care to the plaintiffs. ${ }^{256}$ The parent advising the management of the relevant operations of the subsidiary is relatively commonplace, and undoubtedly easier for plaintiffs to prove, than the parent taking over or controlling the management of these operations. The Lungowe judgment also specifies that when it comes to group-wide policies, failing to act in circumstances where the parent company holds itself out as acting may be sufficient to incur the relevant responsibility. ${ }^{257}$ Again, it may be easier for plaintiffs to prove that the parent company should have done something but did not, than to prove that the parent took over or controlled the subsidiary.

This less restrictive approach is to be welcomed. The Supreme Court took the opportunity in Okpabi to correct the Court of Appeal's error in that case of requiring that the parent company control the subsidiary's operations or have direct responsibility for practices or failures which are the subject of the claim, and to solidify its incremental expansion in direct parent company liability. This was an important opportunity to clarify the law and its application to the case in light of the ruling in Lungowe. There was no such opportunity in the Unilever case but, as noted by one commentator:

It is plausible that, given the guidance of the Supreme Court in Vedanta, a first instance judge [in the Unilever case] might now approach the relevant legal and factual analysis around parent company liability less restrictively and consider that the relatively low jurisdictional bar was cleared.258

The Court of Appeal in the Unilever case was plainly wrong to resolve the question of the parent company's duty of care using the

\footnotetext{
256 Vedanta Resources PLC v. Lungowe [2019] UKSC 20 ๆ 49 (Eng.).

257 Id. ๆ 53; see also McCorquodale, supra note 223.

258 Owen \& Bristow, supra note 255; see also AAA v. Unilever PLC [2017] EWHC (QB) 371 (Eng.).
} 
test of proximity that is applied in novel cases: this approach was rejected in both Lungowe ${ }^{259}$ and Okpabi. ${ }^{260}$ If Okpabi does not settle and goes to trial, the Supreme Court's approach in Lungowe and Okpabi will be applied to the facts ascertained through discovery, providing greater elucidation of direct liability of parent companies. ${ }^{261}$ This process of elucidation has also occurred through the spread of the direct liability argument to other jurisdictions, the subject addressed next.

\section{DIRECT LIABILITY SPREADS TO OTHER JURISDICTIONS}

This Part identifies key trends in transnational business and human rights litigation from jurisdictions outside the United States and the United Kingdom. The expansion of tort litigation through direct liability claims has been taken up in other common law jurisdictions, notably Canada and, to a lesser extent, Australia. The application of English common law precedent to claims brought in civil law jurisdictions has transmitted the direct liability trend outside common law jurisdictions. It is to these claims that this Part turns first.

\section{a. Civil Law Jurisdiction Cases in which English Common Law is the Applicable Law}

The application of English common law precedent to claims brought in civil law jurisdictions has occurred in a handful of transnational business and human rights cases. In the Dutch case of Akpan v. Royal Dutch Shell PLC,262 the applicable law was Nigerian

259 Vedanta Resources PLC v. Lungowe [2019] UKSC 20, [ๆ 54] (Eng.).

260 Okpabi v. Royal Dutch Shell PLC [2021] UKSC 3 [ 1 151] (Eng.).

261 This has only happened before in Chandler v. Cape PLC [2012] EWCA (Civ) 525 (Eng.) and in Kalma v. African Minerals Ltd. [2018] EWHC 3506 (QB) (Eng.), which was lost by the plaintiffs after the trial, the judge finding that there was no evidence to support the allegation that the parent company was involved in the negligent acts of primary perpetrator, the Sierra Leone police.

262 Rb's Den Haag 30 januari 2013, JOR 2013, 162 m.nt. JF (Akpan/Royal Dutch Shell PLC) (Neth.); Hof's Den Haag 18 december 2015, NJF 2013, 3857 m.nt. F.C.S. Warendorf (Akpan/Royal Dutch Shell PLC) (Neth.); Hof's Den Haag 29 januari 2021, NJ 2021, 77 m.nt. (Milieudefensie/Shell Petroleum NV) (Neth.). 
law, which draws on English precedent. ${ }^{263}$ The facts in Akpan were similar to those in Okpabi: the allegations concern oil spills and pollution in the Niger Delta and the defendant corporations are Royal Dutch Shell PLC (the Anglo-Dutch parent company) ${ }^{264}$ and Shell Petroleum and Development Company Ltd. (the Nigerian subsidiary).265 A major difference is that Akpan is not a class action like Okpabi, but rather three parallel claims brought by individual fishermen and Friends of the Earth (Netherlands). ${ }^{266}$ The suit alleges that the oil spills occurred due to a lack of maintenance of a wellhead and inadequate safety measures to prevent sabotage. 267

Notably Akpan was heard prior to the trilogy of English cases discussed in Part IV above. At trial, the District Court of The Hague, applying Nigerian law and, by extension, English law, had to apply the principles from the case of Chandler $v$. Cape to the facts at hand. ${ }^{268}$ Its decision was to dismiss the claim against parent company, RDS.269 The court decided that RDS was not engaged in the same business as SPDC, one of the indicia from Chandler of parent company direct liability, because it was not engaged in oil production in Nigeria like SPDC.270 Therefore, RDS was not expected to have better knowledge of how to prevent risks from harm caused by oil spills and pollution than SPDC, meaning that there was no proximity between the parties to ground a duty of care. ${ }^{271}$ The court therefore found no reason to depart from the principle in Nigerian and English tort law that there is no general duty of care to prevent others from suffering harm as a result of the activities of third parties.272 It did find for the plaintiffs against

\footnotetext{
263 Id.

264 Hof's Den Haag 18 december 2015, NJF 2013, 3857 m.nt. F.C.S. Warendorf (Akpan/Royal Dutch Shell PLC) (Neth.). Although RDS is registered in the United Kingdom, the Dutch courts can assert jurisdiction over it because the company is actually headquartered in the Netherlands, and such jurisdiction in permissible under arts. 4 and 63(1) of the Brussels Regulation, supra note 51.

265 Rb's Den Haag 30 januari 2013, JOR 2013, 162 m.nt. JF (Akpan/Royal Dutch Shell PLC) (Neth.).

$\begin{array}{ll}266 & I d . \\ 267 & I d . \\ 268 & I d . \\ 269 & I d . \\ 270 & I d . \\ 271 & I d . \\ 272 & I d .\end{array}$
} 
SPDC, however, making this one of the only transnational business and human rights claims against a TNC to succeed at trial. ${ }^{273}$

The Dutch court's restrictive approach to proximity was later mirrored by the English courts in Okpabi. Akpan is not legal precedent for the English courts, but it is certainly conceivable that the courts in Okpabi were aware of the Dutch litigation, not least because Shell is a defendant in both cases. The Akpan plaintiffs appealed the District Court decision, and their appeal was successful. ${ }^{274}$ By this time, the Lungowe judgment had been issued by the U.K. Supreme Court, further elucidating the principles of direct parent company liability. The court found a limited duty of care in relation to the parent company's response to the spill. ${ }^{275}$ The judgment is in Dutch, but Lucas Roorda reports the following outcome:

Based on internal documents, bonus policies and a witness statement, the court concludes that after 2010 RDS was actively trying to limit the amount of oil spills in SPDC's operations, amongst other things by installing Leak Detection Systems (LDS) in its pipelines. The court thus finds that with respect to the installation of an LDS in the Oruma pipeline, where it had not been installed at the time of the proceedings, RDS had a duty of care to the claimants. It orders Shell to insure it is installed within a year. ${ }^{276}$

Thus, this case is the first time that plaintiffs have established, following a full, merits trial, a common law duty of care on a parent company towards them. ${ }^{277}$ A further case concerning oil pollution in the Niger Delta is currently before the Italian courts. 278 This is against a different corporate defendant: the Italian oil company ENI. ${ }^{279}$ Nigerian law and, by extension, English common law is the

\footnotetext{
273 Id.

274 Hof's Den Haag 29 januari 2021, NJ 2021, 77 m.nt. (Milieudefensie/Shell Petrpoleum NV) (Neth.).

275 Id.

276 Lucas Roorda, Wading Through the (Polluted) Mud: the Hague Court of Appeals Rules on Shell in Nigeria, RigHTS AS UsUAL (Feb. 2, 2021), https://rightsasusual.com/?p=1388 [https://perma.cc/89JQ-FKAV].

277 Id.

278 Essex Bus. \& Hum. RTs. Project, Legal Opinion ON ENGLish COMMON LAW PRINCIPLES OF TORT: ODODO FRANCIS TIMI V ENI AND NigERIAN AGIP OIL COMPANY (NAOC) 4-6 (2018).

279 Id.
} 
applicable law and the plaintiffs allege that the parent company is directly liable in negligence. ${ }^{280}$ Thus the Akpan litigation is not an isolated example.

Another case in which English common law precedent has been applied in a civil law jurisdiction is Jabir v. KiK. ${ }^{281}$ A novel feature of this case that differentiates it from most of the cases discussed so far is that it concerns a first tier supplier, not a subsidiary. ${ }^{282}$ As noted above, when corporations' overseas operations are conducted contractually through suppliers and licensees, the contractual veil operates to prevent plaintiffs attributing direct liability to the lead company.283 In Jabir, the plaintiffs attempted to persuade a German court that the direct liability precedent from Chandler applies when the relationship between the companies is one of contract rather than of equity. ${ }^{284}$ The plaintiffs are victims of a fire in a textile factory in Pakistan run by a Pakistani company called Ali Enterprises (A.E.), and the families of those who died in the fire. $285 \mathrm{KiK}$ is a German low-cost apparel retailer. ${ }^{286}$ A.E. produced almost exclusively for KiK. 287 The allegation in the case is that many of the factory windows were barred, the emergency exits locked, and the building had only one unobstructed exit, impeding the exit of employees who, as a consequence, suffocated or were burned alive inside. ${ }^{288}$ The factory had recently been the subject of a health and safety audit

\footnotetext{
$280 \quad I d$.

281 See Landgericht Dortmund [Dortmund District Court] Jan. 10, 2019, 7 O 95/15, Justiz-online (Ger.) http://www.justiz.nrw.de/nrwe/lgs/dortmund/lg_dortmund/j2019/7_O_95_1 5_Urteil_20190110.html [https://perma.cc/FQP5-JJKE].

282 See also Das v. George Weston Ltd., 2018 CanLII C64146; C64679 (Can.) (another Canadian case concerning the collapse of the Rana Plaza building in Bangladesh that was dismissed by the courts).

283 Anil YilmaZ-VASTARdis \& SHELdon LEADER, Univ. Of EsSEX, IMPROVING Paths to Business Accountability fOR Human Rights Abuses in the Global SuPply CHAINS: A LEGAL GIDE (Dec. 2017) http:/ / repository.essex.ac.uk/21636/1/Improving-Paths-to-Accountability-forHuman-Rights-Abuses-in-the-Global-Supply-Chains-A-Legal-Guide.pdf [https://perma.cc/N8AC-G8SN].

284 Landgericht Dortmund [Dortmund District Court] Jan. 10, 2019, 7 O 95/15, Justiz-online (Ger.) http://www.justiz.nrw.de/nrwe/lgs/dortmund/lg_dortmund/j2019/7_O_95_1 5_Urteil_20190110.html [https://perma.cc/FQP5-JJKE].

$\begin{array}{ll}285 & I d . \\ 286 & I d . \\ 287 & I d . \\ 288 & I d .\end{array}$
}


by an Italian social auditing firm, acting on behalf of KiK. ${ }^{289}$ These safety problems were not identified.290 The plaintiffs sued the company in Germany for compensation for personal injury and death. ${ }^{291}$ Pakistani law, which is the applicable law in the case, is derived from the common law, meaning that English law precedent is used in novel cases. ${ }^{292}$

A brief on the applicable law that was submitted to the German court argues that the case deals with the responsibilities of purchasers of goods from suppliers in situations in which there is not the arm's length relationship characteristic of typical commercial situations. ${ }^{293}$ It alleges that KiK was in a position similar to that of the parent company in Chandler. KiK

had made a commitment to the health and safety policy to be followed by [A.E.]; [Kik] had enough potential influence over the supplier making it able to fully implement its standards had it wished to; [KiK] had, via its auditor, specialist knowledge of the criteria for distinguishing adequate from inadequate factory safety provisions which A.E. did not have; and [KiK] was in a line of business that overlapped with that of A.E. sufficiently to make it fair that its knowledge and experience should be brought to bear on the improvements 294

to safety that should have been made. The joint effect of this superior knowledge of current safety criteria, taken together with its failure to intervene to rectify working conditions, created an environment in which A.E. relied on KiK's guidance and was encouraged to continue its workplace practices due to the absence of pressure from $\mathrm{KiK}$.

The case did not reach trial however, meaning that these arguments on parent company liability were not fully considered in court. Having been granted legal aid by the court on the basis of an arguable case, ${ }^{295}$ the court later dismissed the case because the

289 Id.

290 Id.

291 Id.

292 Id.

293 See Legal Opinion on Jabir, supra note 176.

294 Id. \ 14.

295 KiK muss wegen Fabrikbrand vor Gericht, ZEIT ONLINE (Aug. 30, 2016), http://www.zeit.de/wirtschaft/ unternehmen/2016-08/schadenersatzklage-kikpakistan-brandprozesskostenhilfe-textilfabrik (last visited May 22, 2021). 
statute of limitation had expired. ${ }^{296}$ The outcome of the litigation was therefore reached on process rather than substance, and the plaintiffs have appealed. ${ }^{297}$

\section{b. Canadian Cases}

As a major global center for mining, Canada has been a key jurisdiction for claims against parent companies in this sector in which direct liability is alleged. Choc v. Hudbay Minerals, Inc. ${ }^{298}$ is one such case. The allegation that lies behind this litigation is that the security personnel at Hudbay Minerals' former mining project in Guatemala along with Guatemalan police and military engaged in numerous human rights abuses, including shooting, killing and rape, when evicting local people from a mine site. ${ }^{299}$ The security personnel were hired by Hudbay's $98.2 \%$ owned subsidiary. ${ }^{300}$ The plaintiffs' primary argument is an allegation that Hudbay owed a direct duty of care to them to prevent the harms in question. 301 In the alternative, they seek to hold Hudbay liable by piercing the corporate veil. ${ }^{302}$

The case has survived a preliminary challenge on the basis of forum non conveniens and a motion to dismiss on the merits of the claim. ${ }^{303}$ With regard to the allegation of direct negligence against the parent company, the court ruled that the plaintiffs had

296 Landgericht Dortmund [Dortmund District Court] Jan. 10, 2019, 7 O 95/15, Justiz-online

http://www.justiz.nrw.de/nrwe/lgs/dortmund/lg_dortmund/j2019/7_O_95_1 5_Urteil_20190110.html [https://perma.cc/FQP5-JJKE].

297 KiK Lawsuit (re Pakistan), Bus. \& Hum. Rts. Res. Centre, https://www.business-humanrights.org/en/latest-news/kik-lawsuit-re-pakistan / [https://perma.cc/58ZD-FG9X].

298 Choc v. Hudbay Minerals, Inc., [2013] 116 O.R. 3d 764 (Can. Ont. Sup. Ct. J.); see also Garcia v. Tahoe Resources Inc., 2017 BCCA 39 (Can.) (a similar case that was recently settled); Skinner, supra note 42, at 1836; Pan American Silver, Pan American Silver Announces Resolution of Garcia v. Tahoe Case, Bus. \& HuM. RTs, RESOURCE CTR. (Jul. 30, 2019), https://www.business-humanrights.org/en/panamerican-silver-announces-resolution-of-garcia-v-tahoe-case [https://perma.cc/8QHS-EFE2].

Ct. J.).

299 Choc v. Hudbay Minerals, Inc., [2013] 116 O.R. 3d 764, I 4 (Can. Ont. Sup.

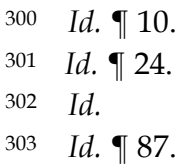


sufficiently pleaded both foreseeability and proximity between the plaintiffs and defendants to found a novel claim such as this. ${ }^{304}$ The test for foreseeability is whether the harm was "a reasonably foreseeable consequence of the defendant's act." 305 The plaintiffs argue inter alia that the company knew that the security forces frequently used violence to evict people and that this had happened at the proposed mine site on a previous occasion. ${ }^{306}$ These allegations of a high level of parent company knowledge were sufficient for the court to find foreseeability arguable. 307 The test for proximity is "the circumstances of the relationship inhering between the plaintiff and the defendant are of such a nature that the defendant may be said to be under an obligation to be mindful of the plaintiff's legitimate interests in conducting his or her affairs." 308 The court found that the allegations sufficiently alleged proximity. ${ }^{309}$ These allegations included statements made by Hudbay asserting its direct involvement and its high level of operational oversight of the subsidiary and the security personnel, and that it did everything in its power to ensure the evictions were carried out in accordance with human rights. ${ }^{310}$ The court granted Amnesty International Canada intervener status in the litigation. 311 Amnesty International cited the English case law discussed above to support its argument that parent company liability is not new to tort law, and that the imposition of a duty of care was therefore foreseeable to the corporate defendants. ${ }^{312}$ This argument, and the relevance of the English law precedent, will be considered at trial. ${ }^{313}$

J.).

304 Choc v. Hudbay Minerals, Inc., [2013] 116 O.R. 3d 764 (Can. Ont. Sup. Ct.

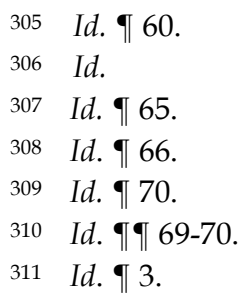

312 Factum of the Intervenor, Amnesty International Canada If 25, Choc v. Hudbay Minerals, Inc., [2013] 116 O.R. 3d 764 (Can. Ont. Sup. Ct. J.).

313 The case has remained in discovery for a number of years. On January 21, 2020, the Superior Court of Justice in Ontario ruled in favor of the plaintiff's in response to Hudbay's motion to block them from amending their complaint to include further details of rapes committed by the mining security forces. See Hudbay Minerals Lawsuits (re Guatemala), Bus. \& Hum. RTS. RESOURCE CTR., https:/ / www.business-humanrights.org/en/latest-news/hudbay-minerals-laws uits-re-guatemala-3/ [https://perma.cc/L5EC-PU5P]. 
In Nevsun Resources Ltd. v. Araya, the plaintiffs, three Eritrean refugees, claim, on behalf of themselves and more than 1,000 Eritrean workers, that Nevsun is liable in negligence and for breaches of customary international law including forced labor, torture, slavery, and crimes against humanity. 314 The claims relate to Nevsun's alleged complicity in the use of forced labor at a mine site in Eritrea. ${ }^{315}$ The mine is jointly owned by Nevsun $(60 \%)$ and the Eritrean state (40\%). 316 The Eritrean state drafted labor for the mine site using its National Service Program - a system known to amount to use of forced labor. ${ }^{317}$ An attempt by Nevsun to have the claims under customary international law struck out was unsuccessful, the court finding it at least arguable that customary international law forms part of Canada's common law and rejecting the defendant's defenses based on act of state and forum non conveniens. ${ }^{318}$ The decision as it related to customary international law and act of state was the subject of an appeal to the Supreme Court of Canada. In a long-awaited judgment released in February 2020 , the court held by a majority of five to four that the claims based on customary international law could proceed. 319 The majority concluded that under the "doctrine of adoption," peremptory norms of customary international law are automatically adopted into Canadian domestic law, 320 and the plaintiffs' pleadings based on customary international law did not therefore "disclose no reasonable claim." 321 The significance of this ruling is that it opens up the possibility of enforcing customary international human rights law through the common law, making this case more like the old U.S. ATS cases than the new U.K. tort cases. These cases, along with their counterparts in other common law countries, 322 and the

314 Nevsun Resources Ltd. v. Araya, 2020 SCC 5 (Can.) (settled out of court in October 2020); see Peter Muchlinski, Corporate Liability for Breaches of Fundamental Human Rights in Canadian Law: Nevsun Resources Limited v Araya, 1 AmICUS CURIAE 505 (2020); Palombo, supra note 5.

315 Nevsun Resources Ltd. v. Araya, 2020 SCC 5 (Can.).

$316 \quad$ Id. 97.

$317 \quad$ Id. ๆ 310.

$318 \quad$ Id. ๆ $1777-97$.

$319 \quad$ Id. ๆ 132.

$320 \quad$ Id. $₫ 86$.

$321 \quad$ Id. 148.

322 There has also been at least one case in negligence brought against private corporate contractors operating Australia's offshore refugee detention centers claiming they owed duties of care, together with the government, in respect of the 
cases in civil law jurisdictions described above, indicate that the U.K. precedent is being amplified in international jurisprudence.

\section{DIRECT LIABILITY AS A PATH FORWARDS FOR PLAINTIFFS IN THE UNITED STATES}

As can be seen from the preceding discussion, there are reasons to be cautiously optimistic for plaintiffs about the gradual expansion of direct liability in transnational business and human rights litigation in English case law. The jurisdictional veil in cases against parent companies, still a significant hurdle for plaintiffs in U.S. courts, was diminished as an impediment for plaintiffs in the English cases as a result of developments at the European level. ${ }^{323}$ This has placed the focus firmly on the corporate veil, and more specifically on attributing liability to the parent company. Lungowe and Okpabi are clearly an important legal milestone for plaintiffs in tackling this hurdle. To have two decisions from the U.K. Supreme Court on the subject within a two-year period is highly significant to the shaping of direct parent company liability. With the use of English law precedent in some common law jurisdictions, and in the civil law jurisdiction cases described above, the significance of this case extends beyond England. While wholesale reform of the corporate veil in transnational business and human rights litigation remains elusive, the incremental expansion of direct parent company liability offers a pragmatic way forward for plaintiffs.

In contrast, the situation for plaintiffs in the United States is far more sanguine. The outcome of Kiobel came as a blow to the corporate accountability movement. Up until that point most, if not all, ATS cases against corporate defendants concerned harmful events that occurred overseas. The decision in Kiobel that the principles underlying the presumption against extraterritoriality apply to the ATS therefore represented a sea-change in the interpretation of the statute and, going forward, the touch and concern test presents an enormous hurdle to plaintiffs. The closing

health and wellbeing of the refugees in their control. See Kamasaee $v$ Commonwealth [2015] VSC 148 (Austl.).

323 Brussels Regulation, supra note 51; Owusu v. Jackson [2005] ECR 1445 (Eng.). Note that forum non conveniens type arguments are used by defendants to defend claims made against foreign corporations. See Vedanta Resources PLC v. Lungowe [2019] UKSC 20, ๆ 13 (Eng.). The departure of the United Kingdom from the European Union has implications here. See Aristova, supra note 200. 
off of litigation against foreign corporations means that all aspects of culpable behavior-those of the parent and those of the subsidiary-cannot be examined in the same ATS case. Of greater significance, corporate liability under international law, and consequently under the statute, is precarious, with a decision from the Supreme Court on this subject coming in 2021.324

When it comes to attributing liability to the parent company in transnational business and human rights litigation, the test for agency-the primary argument used by plaintiffs seeking to attribute liability to parent companies in the United States - is more exacting for plaintiffs to prove than the direct liability test from the English line of cases. While both tests involve an examination of the relationship between the parent company and the subsidiary, focusing in particular on their interaction over the activities that are the subject of the claim, agency requires that the parent company dominate the relevant activities, while direct liability considers more broadly the extent to which the parent company takes over, intervenes in, controls, supervises, or advises the management of the relevant operations. Put simply, the former entails more parent company involvement than the latter. The Lungowe judgment also provides that a duty of care may be imposed when, through groupwide policies, the parent company holds itself out as supervising the subsidiary, but it omits to do so in practice. ${ }^{325}$ This is highly relevant in the context of global business, where expectations for the corporate group are communicated through group-wide policies on subjects such as security, health and safety, the environment, and human rights. For example, in Acuña-Atalaya the parent company sets standards and provides policies for its subsidiary, including on human rights and security, and is alleged to have failed to ensure that these were followed. ${ }^{326}$ By attributing liability where a company holds itself out as supervising, but omits to do so in practice, direct liability could be the key to success for the plaintiffs in this case.

Agency is a means by which the wrongs of the subsidiary can be visited upon the parent. Direct liability, on the other hand, looks squarely at the parent company and attributes liability for its role in the wrongdoing of the subsidiary. There is an important difference

\footnotetext{
324 Nestlé USA, Inc. v. Doe I, 141 S. Ct. 188 (2020) (cert. granted).

325 Vedanta Resources PLC v. Lungowe [2019] UKSC 20, ๆ 20 (Eng.); see also McCorquodale, supra note 223.

326 Acuña-Atalaya v. Newmont Mining Corp., 308 F. Supp. 3d 812 (D. Del. 2018), vacated and remanded, 765 F. App'x 811 (3d Cir. 2019).
} 
here, in terms of framing the wrongdoing and locating the problem. It is not the subsidiary doing wrong overseas and the parent company being found liable for it, but the parent company's acts and omissions, some of which occur at headquarter level, that are under scrutiny.

What lessons can be taken from the positive U.K. experience? At least one leading scholar contends that the U.S. courts may at some point accept the direct liability argument in transnational tort litigation, implicitly clarifying that there is no reason in principle for courts not to do so. ${ }^{327}$ Acceptance of the direct liability argument by the U.S. courts offers a path forward for transnational business and human rights litigation. Not only is direct liability easier for plaintiffs to establish, diminishing one of the many hurdles that plaintiffs in such cases face, but using this argument also allows the courts to look more broadly at the interaction between a parent and subsidiary company and attribute liability for involvement that falls short of domination but is nonetheless culpable behavior on the parent's part that plays a significant role in the subsidiary's wrongdoing. By examining the interaction between parent and subsidiary, and the parent and the victim, and focusing on the culpable actions/omissions that occurred at headquarter level, direct liability connects transnational business and human rights cases with the U.S. jurisdiction. This provides a powerful argument to counter forum non conveniens, meaning that in cases like AcuñaAtalaya, the courts are in better position to find a meaningful nexus between the United States and the decisions and practices that form the subject of the claim, and will be less likely therefore to dismiss on forum non conveniens grounds. It also strengthens the argument that federal or state law is the applicable law in a given case, ${ }^{328}$ and is in keeping with the focus on domestic culpable conduct that the touch and concern test from Kiobel requires of ATS litigation.

At a higher level, the English case law may go some way to assuage the U.S. courts' fear, underpinning the decisions in Kiobel, Bauman, and Jesner, about jurisdictional overreach of the U.S. courts and, consequently, impact on foreign relations. This applies to federal courts in ATS claims and federal or state courts in conventional tort claims. It is clear from the direct liability line of cases that parent company home state courts outside the United

\footnotetext{
327 Curran, supra note 57, at 443.

328 See Alford, supra note 13 (discussing conflict of laws in transnational business and human rights litigation).
} 
States are accepting jurisdiction over transnational business and human rights claims. While not serving as precedent for the U.S. courts, these cases can nonetheless be used by plaintiff lawyers to evidence a global trend of provision of access to remedy in transboundary human rights cases in which the parent company is sufficiently involved in the operations of the subsidiary. This trend can be linked to the commentary to the UNGPs, ${ }^{329}$ which tells states that they should provide access to remedy in extraterritorial cases when host state courts do not,330 and likewise to the General Comment of the Committee on Economic Social and Cultural Rights on this subject, which holds that the extraterritorial obligation to protect requires state parties to take steps to prevent and redress infringements of Covenant rights that occur outside their territories due to the activities of business entities over which they can exercise control, especially in cases where the remedies available to victims before the domestic courts of the state where the harm occurs are unavailable or ineffective. 331

329 Note that the U.K. Supreme Court declined to reference international standards in Lungowe. But see McCorquodale, supra note 223. Such standards have been referenced in certain cases though. See Choc v. Hudbay Minerals, Inc., [2013] 116 O.R. 3d 764 (Can. Ont. Sup. Ct. J.) (noting that Amnesty, an intervener in the case, argued that the UNGPs and other norms support the view that a duty of care may exist in circumstances where a parent company's subsidiary is alleged to be involved in gross human rights abuses). Amnesty also argued that, because the Canadian government endorsed the UNGPs, Canadian courts should have no difficulty in drawing upon them in considering whether a Canadian corporation owes a duty of care. Id. $\uparrow 26$.

330 UNGPs, supra note 58, Principle 26 and Commentary.

331 See Econ. \& Soc. Council, Comm. on Econ., Soc. \& Cultural Rts., General Comment No 24, U.N. Doc. E/C.12/GC/24 (2017); see also Econ. \& Soc. Council, Comm. on Econ., Soc. \& Cultural Rts., General Comment No. 14, II 39, Docs. E/C.12/2000/4 (2000) (stating that in order to comply with their international obligations, state parties to ICESCR have to respect the enjoyment of the rights stipulated in the Covenant in other countries, inter alia, by preventing third parties from violating the right in other countries "if they are able to influence these third parties by way of legal or political means, in accordance with the Charter of the United Nations and applicable international law"); Econ. \& Soc. Council, Comm. on Econ., Soc. \& Cultural Rts., General Comment No. 15, I 33, U.N. Docs. E/C.12/2002/11 (2003) (making explicit reference to preventing companies from violating the right to water of individuals and communities in other countries); Econ. \& Soc. Council, Comm. on Econ., Soc. \& Cultural Rts., General Comment No. 19, ๆ 54, U.N. Docs. E/C.12/GC/19 (2009).

Similar statements have been made through the use of concluding observations. See, e.g., Comm. on the Elimination of Racial Discrimination, Concluding Observations of the Committee on the Elimination of Racial Discrimination: Canada, I 17, U.N. Doc. CERD/C/CAN/CO/18 (2007); Comm. on the Elimination 


\section{CONCLUSION}

This Article has considered one impediment to access to remedy for victims of human rights violations at the hands of corporate actors, namely the corporate veil, and in light of this impediment, how to attribute liability to parent companies in transnational business and human rights litigation. Further impediments were acknowledged, prominent among them the jurisdictional veil. Future scholarship should consider extraterritoriality in the context of transnational business and human rights litigation, examining the operation of the presumption against extraterritoriality/prohibition on ATS claims against foreign corporations, and the different approach to this issue under foreign laws such as European law. ${ }^{332}$ The decision of the U.K. Supreme Court in Lungowe on the forum non conveniens question, discussed in other works, 333 may be instructive.

Future scholarship should also address the broader question of whether the United Kingdom-or now perhaps Canada-is becoming the new forum for victims to bring human rights litigation against corporate defendants. The United States provided such victims with some prospect of access to remedy through the cause of action under the ATS and through a wide test for personal jurisdiction over corporate defendants. The United Kingdom on the other hand traditionally remained adherent to the strictures of the corporate veil. 334 This Article has plotted the trend whereby the United States has restricted access to remedy for such victims, meanwhile the United Kingdom has opened up a route for plaintiffs

of Racial Discrimination, Concluding Observations of the Committee on the Elimination of Racial Discrimination: United States, I 30, U.N. Doc. CERD/C/USA/CO/6 (2008); Human Rts. Comm., Concluding Observations on the Sixth Periodic Report of Germany, I 16, U.N. Doc. CCPR/C/DEU/CO/6 (2012); see also Econ. \& Soc. Council, Comm. on Econ., Soc. \& Cultural Rts., Concluding Observations on the Fourth Periodic Report of Austria, 1 12, U.N. Doc. E/C 12/AUT/CO/4 (2013); Econ. \& Soc. Council, Comm. on Econ., Soc. \& Cultural Rts., Concluding Observations on the Fifth Periodic Report of Norway, I 6, U.N. Doc. E/C 12/NOR/CO/5 (2013).

332 For a discussion of the proper jurisdictional limits of the ATS, see Doug Cassel, Suing Americans for Human Rights Torts Overseas: The Supreme Court Leaves the Door Open, 89 Notre DAME L. ReV. 1773 (2014).

333 See Gabrielle Holly, Vedanta v. Lungowe Symposium: A Non Conveniens Revival-The Supreme Court's Approach to Jurisdiction in Vedanta, OPINIO JURIS (Apr. 24, 2019), https://opiniojuris.org/2019/04/24/vedanta-v-lungowe-symposium-anon-conveniens-revival-the-supreme-courts-approach-to-jurisdiction-in-vedanta $\%$ $\mathrm{EF} \% \mathrm{BB} \% \mathrm{BF} /[$ https://perma.cc/WZ7T-Z2Y2].

334 Adams v. Cape Industries PLC [1989] AC 433 (Eng.). 
to attribute liability to parent companies through direct liability. The reticence on the part of the U.S. courts to provide access to remedy to foreign plaintiffs where human rights violations are alleged against corporate actors stands in contrast to the country's willingness to extend its jurisdiction extraterritorially in other fields, for instance through expansive claims to jurisdiction in the field of competition law. ${ }^{335}$ The United Kingdom's openness to such claims may in part be explained by its membership of the European Union, which has explicitly encouraged extraterritorial jurisdiction where host state remedies for business and human rights cases are elusive and untenable,, 336 prompting the question whether this trend will be reversed after Brexit. 337 These important concerns will no doubt be taken up elsewhere but suffice here to say that, in line with the viewpoint expressed in article, it is hoped that regardless of political developments, the English courts will continue to develop and expand direct parent company liability, and that the U.S. courts will adopt a similar course.

335 See, e.g., United States v. Watchmakers of Switzerland Information Ctr. Inc., No. 96-170, 1962 U.S. Dist. LEXIS 5816, at *137-38 (S.D.N.Y. Dec. 20, 1962); see also MUCHLINSKI, supra note 55, at 134-35.

336 EUROPEAN UNION AgENCY FOR FundAMENTAL RTS., IMPROVING ACCESS TO REMEDY IN THE AREA OF BuSINESS AND HuMAN RigHTS AT THE EU LEVEL (2017); Access to Legal Remedies for Victims of Corporate Human Rights Abuses in Third Countries, EUR. PARL. DOC. PE 603.475 (2019).

337 Brussels Regulation, supra note 51, no longer applies in the United Kingdom post Brexit. See Aristova, supra note 200. The decision on jurisdiction in Lungowe, not discussed in this article, demonstrated an expansive solution to this issue; the Supreme Court found that the case could proceed in England because the plaintiffs lacked access to substantial justice in Zambia. It is hoped that this approach will continue under any new law on jurisdiction. 